\title{
Theoretical Study of Propene Combustion Catalysis of Chromite Spinel: Reaction Mechanism and Relation between Activity and Electronic Structure of Spinel
}

Peng Zhao, ${ }^{a}$ Masahiro Ehara, ${ }^{\mathrm{a}, \mathrm{b}}$ Atsushi Satsuma, ${ }^{\mathrm{a}, \mathrm{c}}$ and Shigeyoshi Sakaki*a

a) Elements Strategy Initiative for Catalysts and Batteries (ESICB), Kyoto University, 1-30 Goryo-Ohara, Nishikyo-ku, Kyoto 615-8245, Japan

b) Institute for Molecular Science, Nishigo-naka 38, Myodai-ji, Okazaki, Aichi 444-8585, Japan

c) Graduate School of Engineering, Nagoya University, Nagoya 464-8603, Japan 


\section{Contents:}

1. Table S1. Translational and rotational entropies of gas molecule .. $\mathrm{S} 3$

2. Figure S1. Geometries of symmetric and stoichiometric slab models..................S3

3. Table S2. Electronic structure of symmetric and stoichiometric slab models...............S3

4. Figure S2. Energy and geometry changes in the reaction between two adsorbed $\mathrm{H}$ and one lattice $\mathrm{O}$ atom yielding one $\mathrm{H}_{2} \mathrm{O}$ with one oxygen vacancy on $\mathrm{ZnCr}_{2} \mathrm{O}_{4}(111)$ surface......S4

5. Figure S3. Geometry and energy of the $\mathrm{Cu}$ - and $\mathrm{Co}$-doped $\mathrm{ZnCr}_{2} \mathrm{O}_{4}(111)$ surfaces.......S4

6. Figure S4. Propene adsorption structures and adsorption energies on $\mathrm{ZnCr}_{2} \mathrm{O}_{4}(111) \ldots \ldots . \mathrm{S} 5$

7. Discussion about O_on-top adsorption of propene on $\mathrm{ZnCr}_{2} \mathrm{O}_{4}(111)$ surfaces..............S5

8. Figure S5. Propene adsorption energies on $\mathrm{ZnCr}_{2} \mathrm{O}_{4}(111)$ using various $U$ values.........S6

9. Figure S6. Energy and geometry changes in the $\mathrm{C}-\mathrm{C}$ bond cleavage of propene..........S6

10. Figure S7. Energy and geometry changes in the $\mathrm{H}$ movement on $\mathrm{ZnCr}_{2} \mathrm{O}_{4}(111) \ldots \ldots \ldots . \mathrm{S} 7$

11. Scheme S1. Reaction courses in the early stage of propene combustion on $\mathrm{ZnCr}_{2} \mathrm{O}_{4}(111)$.S 7

12. Figure S8. Geometry changes in side-reactions of propene combustion................S8

13. Discussion about important side-reactions on the $\mathrm{ZnCr}_{2} \mathrm{O}_{4}(111)$ surface..................S9

14. Reactions of $* \mathrm{CH}_{2}$ and $* \mathrm{CH}$ species on the $\mathrm{ZnCr}_{2} \mathrm{O}_{4}(111)$ surface...................... 10

15. Figure S9. Energy and geometry changes in the $\mathbf{5}^{\mathbf{A}} \rightarrow \mathbf{6}^{\mathbf{A}}$ step on $\mathrm{ZnCr}_{2} \mathrm{O}_{4}(111) \ldots \ldots \ldots . \mathrm{S} 12$

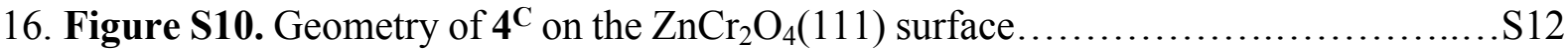

17. Figure S11. Geometries of the TS and FS in the $\mathrm{C}-\mathrm{C}$ bond cleavage of $\mathbf{1 0}^{\mathrm{A}} \ldots \ldots \ldots \ldots . . . \mathrm{S} 13$

18. Figure S12. Energy and geometry changes in the reaction of $1^{\mathrm{C}}$ on $\mathrm{ZnCr}_{2} \mathrm{O}_{4}(111) \ldots \ldots \mathrm{S} 14$

19. Figure S13. Energy and geometry changes in the reaction of ${ }^{*} \mathrm{CHO}$ and the terminal $\mathrm{O}$

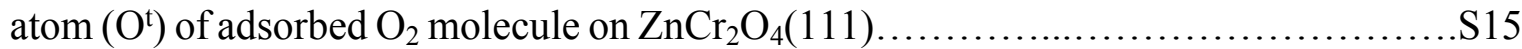

20. Figure S14. Energy and geometry changes in the reactions of ${ }^{*} \mathrm{CH}$ and ${ }^{*} \mathrm{H} \ldots \ldots \ldots \ldots . \mathrm{S} 15$

21. Figure S15. Co-adsorption structure and energy of * $\mathrm{CH}$ and $* \mathrm{H}$ on $\mathrm{ZnCr}_{2} \mathrm{O}_{4}(111) \ldots \ldots . . \mathrm{S} 15$

22. Figure S16. Geometry changes in the propene combustion on the $\operatorname{MgCr}_{2} \mathrm{O}_{4}(111)$,

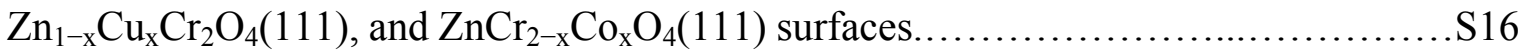

23. Figure S17. Energy changes in the propene combustion on the $\operatorname{MgCr}_{2} \mathrm{O}_{4}(111)$, $\mathrm{Zn}_{1-\mathrm{x}} \mathrm{Cu}_{\mathrm{x}} \mathrm{Cr}_{2} \mathrm{O}_{4}(111), \mathrm{ZnCr}_{2-\mathrm{x}} \mathrm{Co}_{\mathrm{x}} \mathrm{O}_{4}(111)$, and $\mathrm{ZnCr}_{2} \mathrm{O}_{4}(111)$ surfaces.

24. Table S3. Energy changes in propene combustion on the $\operatorname{MgCr}_{2} \mathrm{O}_{4}(111)$, $\mathrm{Zn}_{1-\mathrm{x}} \mathrm{Cu}_{\mathrm{x}} \mathrm{Cr}_{2} \mathrm{O}_{4}(111)$, and $\mathrm{ZnCr}_{2-\mathrm{x}} \mathrm{Co}_{\mathrm{x}} \mathrm{O}_{4}(111)$ surfaces 
Table S1. Translational and rotational entropies $\left(\mathrm{S}_{\mathrm{t}}\right.$ and $\left.\mathrm{S}_{\mathrm{r}}\right)$ of gas molecule calculated by classical methods at $\mathrm{T}=500 \mathrm{~K}$ and $\mathrm{P}=1 \mathrm{~atm}$.

\begin{tabular}{cccccc}
\hline & $\mathrm{E}(\mathrm{eV})$ & $\mathrm{S}_{\mathrm{t}}\left(\mathrm{cal} \mathrm{mol}^{-1} \mathrm{~K}^{-1}\right)$ & $\mathrm{S}_{\mathrm{r}}\left(\mathrm{cal} \mathrm{mol}^{-1} \mathrm{~K}^{-1}\right)$ & $\mathrm{T} \cdot\left(\mathrm{S}_{\mathrm{t}}+\mathrm{S}_{\mathrm{r}}\right)(\mathrm{eV})$ & $\mathrm{E}-\mathrm{TS}(\mathrm{eV})$ \\
\hline $\mathrm{O}_{2}$ & -9.86 & 38.89 & 11.55 & 1.09 & -10.95 \\
$\mathrm{H}_{2} \mathrm{O}$ & -14.24 & 37.18 & 13.46 & 1.10 & -15.33 \\
$\mathrm{CO}_{2}$ & -22.98 & 39.84 & 15.52 & 1.20 & -24.18 \\
$\mathrm{C}_{3} \mathrm{H}_{6}$ & -48.79 & 39.70 & 23.60 & 1.37 & -50.16 \\
acrolein & -47.37 & 40.56 & 25.21 & 1.43 & -48.80 \\
\hline
\end{tabular}

Symmetric slab model $(16 \mathrm{Zn}, 28 \mathrm{Cr}, 640)$

Stoichiometric slab model (16Zn, 32Cr, 64O)
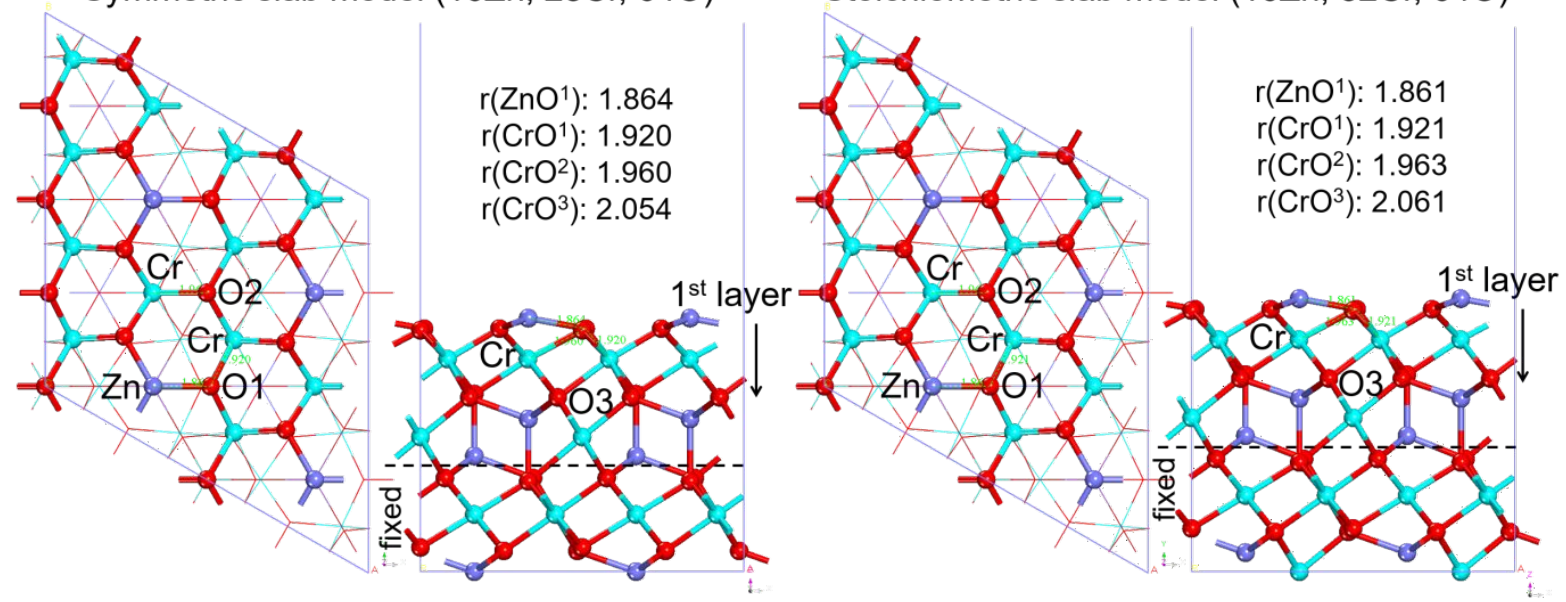

Figure S1. Structural parameters of the symmetric and stoichiometric slab model of the $\mathrm{ZnCr}_{2} \mathrm{O}_{4}(111)$ surface ( $\mathrm{Zn} /$ purple; $\mathrm{Cr} /$ sky blue; O/red). Bond distances are in angstrom.

Table S2. Average value of spin density (in $e$ ), electron populations ${ }^{\text {a) }}$ (in $e$ ), and oxygen vacancy formation energy $y^{\text {b) }}$ in the symmetric and stoichiometric slab models.

\begin{tabular}{ccccc}
\hline & \multicolumn{2}{c}{ Symmetric model } & \multicolumn{2}{c}{ Stoichiometric model } \\
\hline & spin density & electron populations & spin density & electron populations \\
\hline $1^{\text {st }}$ layer O & -0.153 & 7.049 & -0.139 & 7.058 \\
$2^{\text {nd }}$ layer O & -0.065 & 7.187 & -0.058 & 7.170 \\
$3^{\text {rd }}$ layer O & -0.061 & 7.173 & -0.051 & 7.203 \\
$1^{\text {st }}$ layer Cr & 2.772 & 10.173 & 2.797 & 10.189 \\
$1^{\text {st }}$ layer Zn & -0.002 & 10.743 & -0.002 & 10.743 \\
$E_{\text {Ov }}$ b) & $7.51 \mathrm{eV}$ & & $7.68 \mathrm{eV}$ \\
\hline
\end{tabular}

a) Based on Bader charge analysis. ${ }^{\text {b) }} E_{\mathrm{Ov}}=E_{\mathrm{Ov} \text {-slab }}-E_{\text {slab }}$.

Figure S1 and Table S2 show that the symmetrical slab model presents almost the same results as those of the stoichiometric slab model. To eliminate the dipole moment in the perpendicular direction to the surface, we used the symmetrical slab model in this work. 


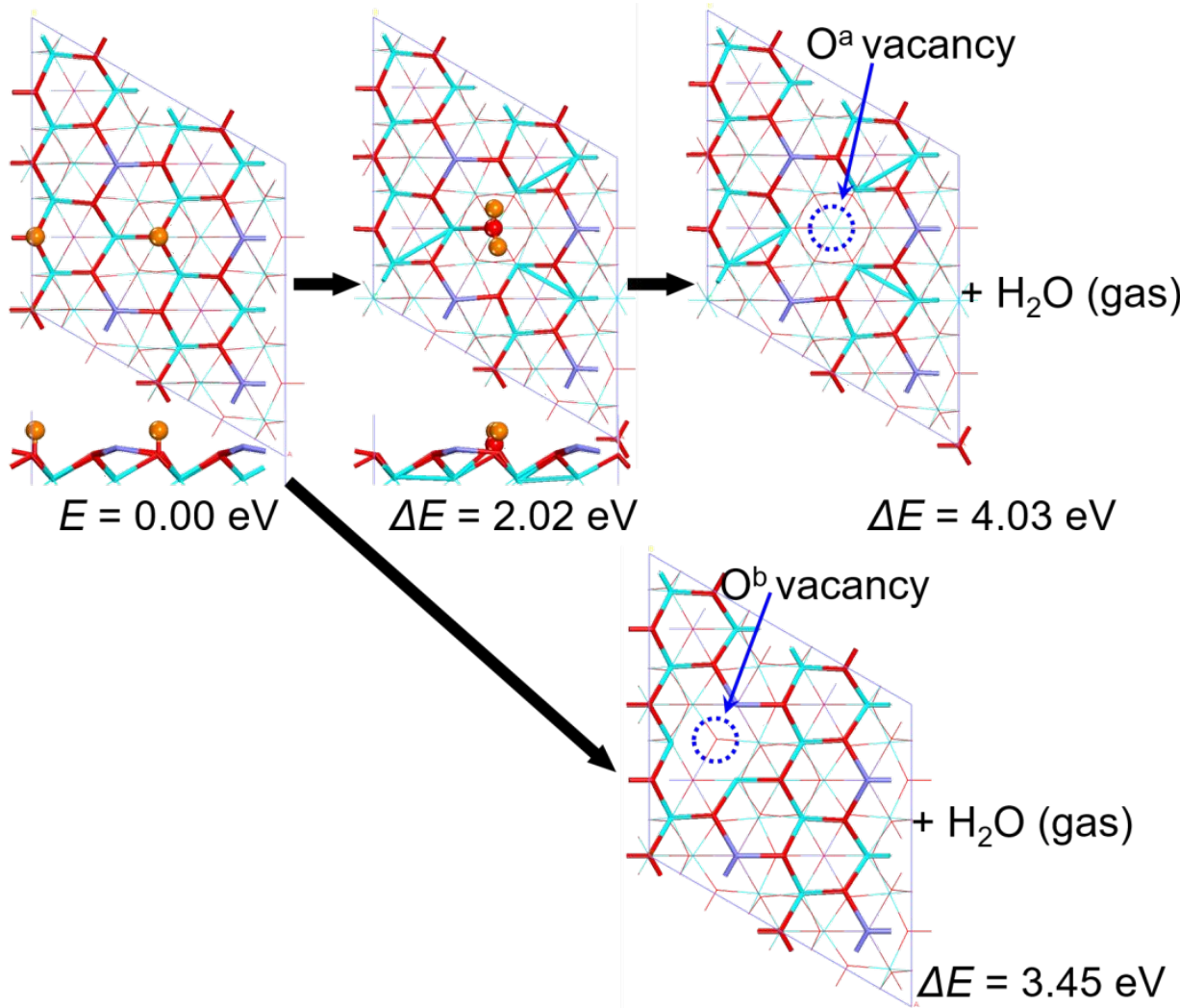

Figure S2. Geometry and energy changes in the oxygen vacancy $\left(\mathrm{O}_{\mathrm{V}}\right)$ formation through the reaction between two adsorbed $\mathrm{H}$ and one lattice $\mathrm{O}$ atom on the $\mathrm{ZnCr}_{2} \mathrm{O}_{4}(111)$ surface (Zn/purple; Cr/sky blue; O/red; H/orange).
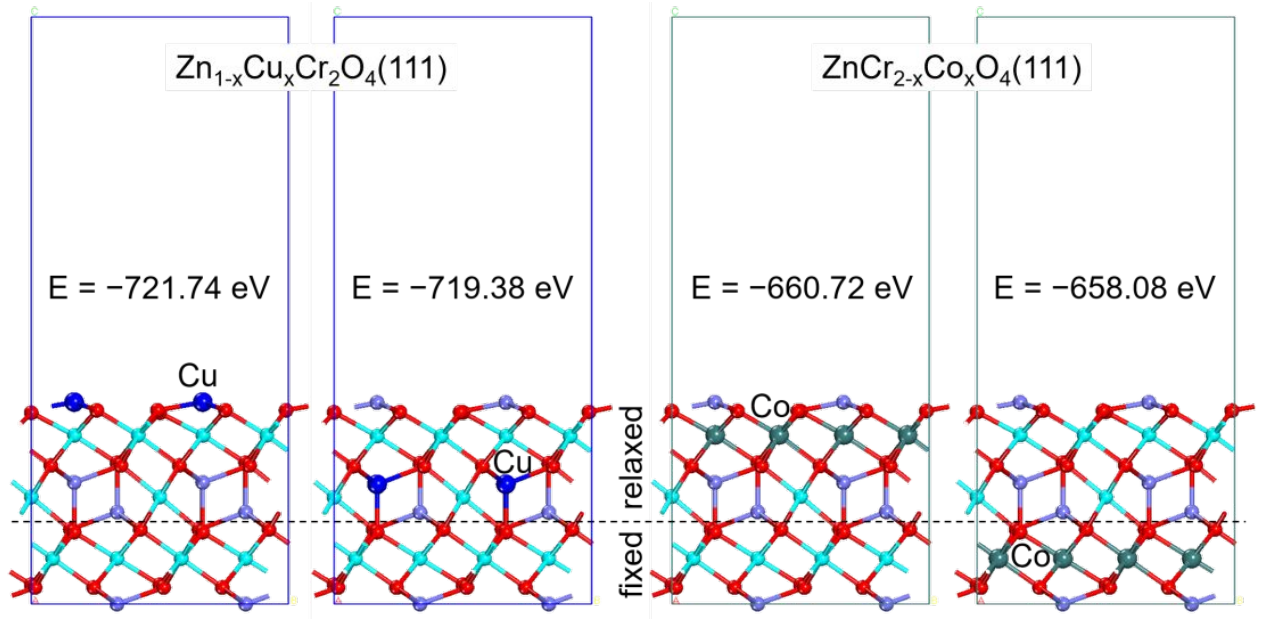

Figure S3. Geometry and energy of the $\mathrm{Cu}$ - and Co-doped $\mathrm{ZnCr}_{2} \mathrm{O}_{4}(111)$ surfaces $(\mathrm{Zn} /$ purple; $\mathrm{Cr}$ /sky blue; $\mathrm{O} / \mathrm{red}$; $\mathrm{Cu} /$ blue; $\mathrm{Co} /$ dark green). 


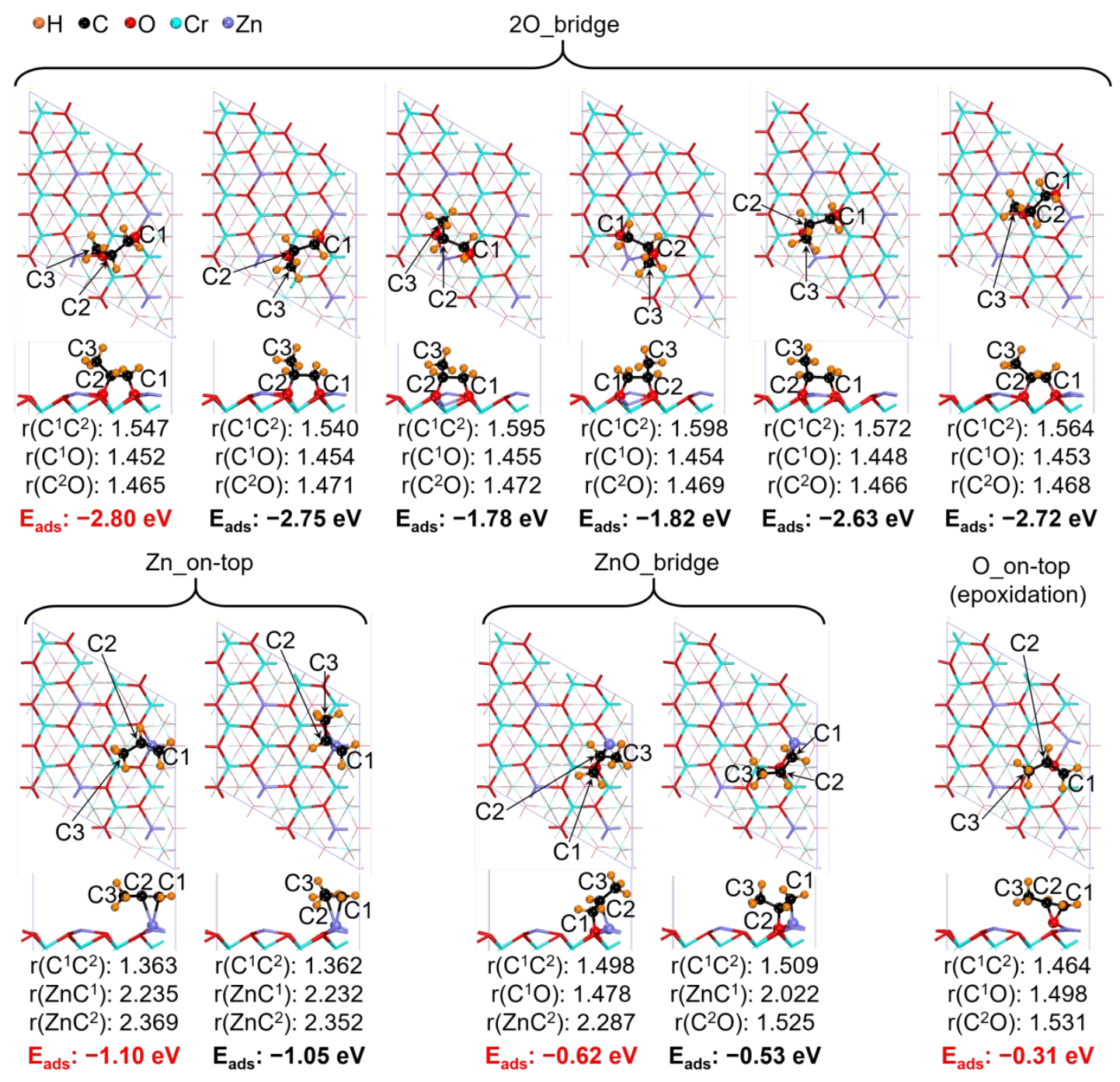

Figure S4. Propene adsorption structures and adsorption energies on the $\mathrm{ZnCr}_{2} \mathrm{O}_{4}(111)$ surface. Bond distances are in angstrom.

Brief Discussion about $O_{-}$on-top adsorption of propene: In Table 1 , the $\Delta q_{C}{ }^{\alpha}+C^{\beta}$ value is considerably positive, but the $q_{\mathrm{O}}$ becomes moderately less negative unexpectedly. Instead, the $q_{\mathrm{Zn}}$ and $q_{\mathrm{Cr}}$ decrease. These features suggest that the surface $\mathrm{Cr}$ and $\mathrm{Zn}$ receive electron density from the $\mathrm{C}_{3} \mathrm{H}_{6}$ but the $q_{\mathrm{O}}$ of the $\mathrm{O}$ atom interacting with the $\mathrm{C}_{3} \mathrm{H}_{6}$ moiety decreases to weaken the exchange repulsion between the occupied $\mathrm{MO}$ of the $\mathrm{O}$ atom and the $\pi \mathrm{MO}$ of propene; note that the $\mathrm{C}^{\alpha}-\mathrm{C}^{\beta}$ distance is shorter than the typical $\mathrm{C}=\mathrm{C}$ double bond. In other words, the $\mathrm{O}$ atom interacting with the $\mathrm{C}_{3} \mathrm{H}_{6}$ moiety does not like to receive electron density but surrounding $\mathrm{Cr}$, $\mathrm{Zn}$, and $\mathrm{O}$ atoms receive electron density from the $\mathrm{C}_{3} \mathrm{H}_{6}$ moiety. 


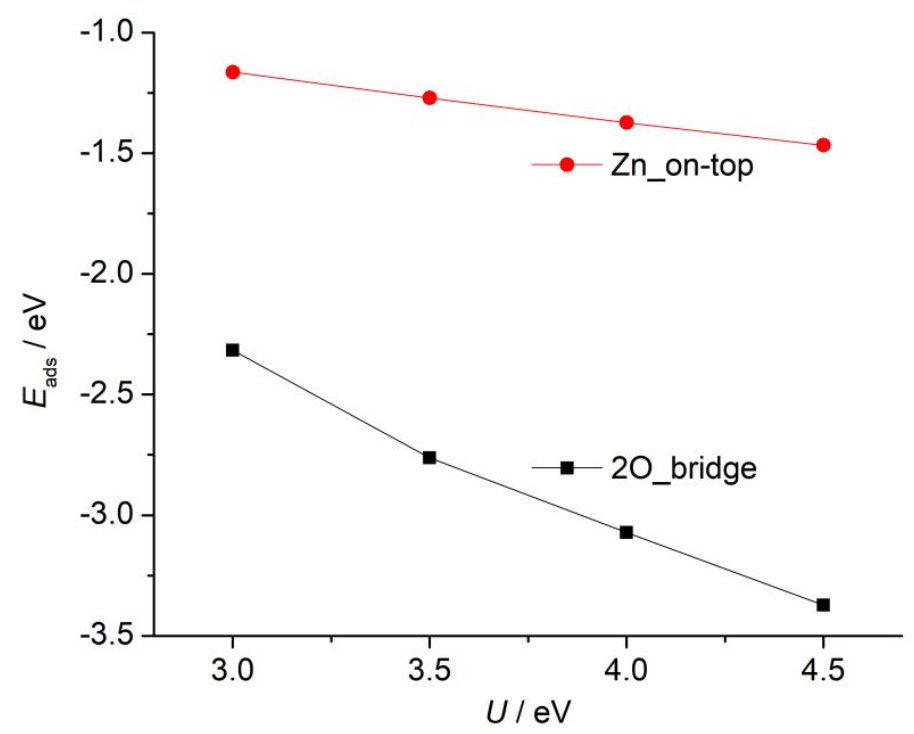

Figure S5. Propene adsorption energies at $\mathrm{Zn}$ _on-top site (red) and 2O_bridge site (black) on the $\mathrm{ZnCr}_{2} \mathrm{O}_{4}(111)$ surface using various $U$ values.

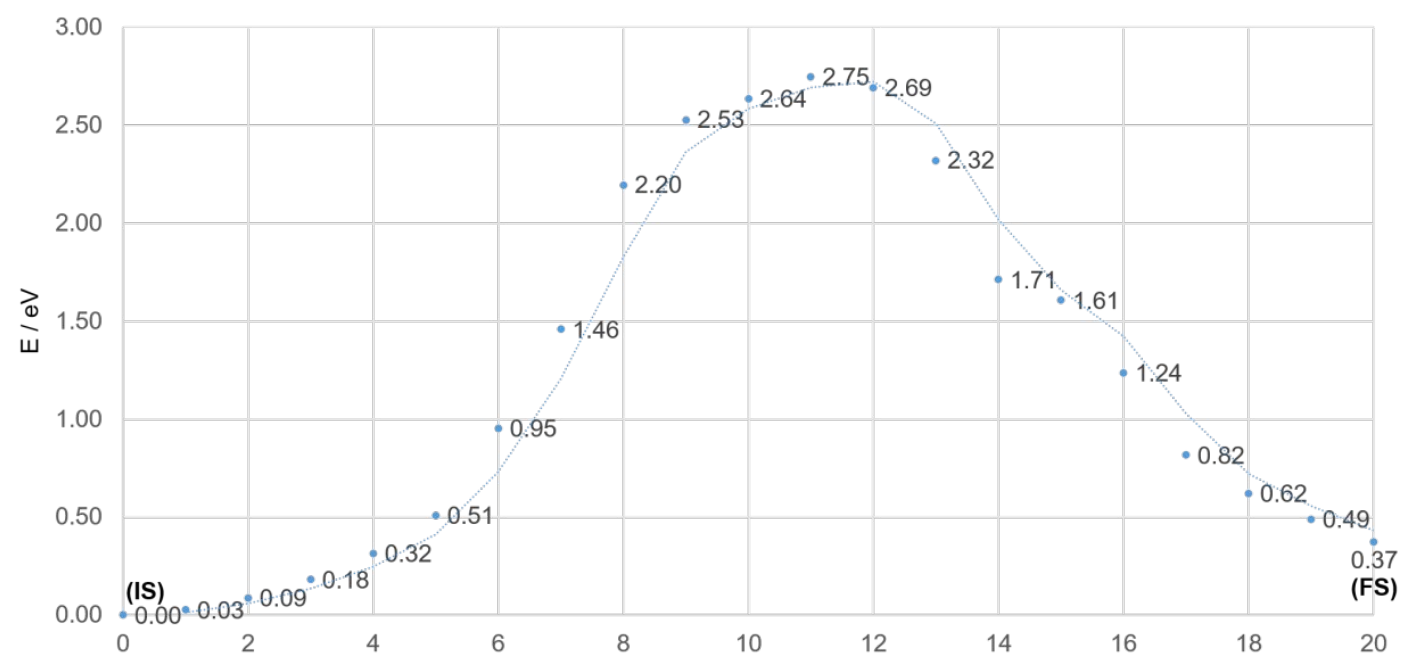

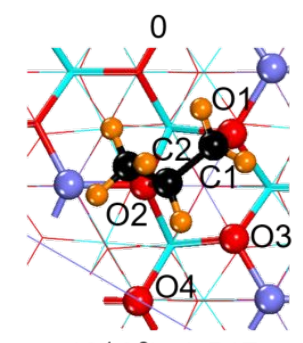

$r\left(C^{1} C^{2}\right): 1.547$

$\mathrm{r}\left(\mathrm{C}^{1} \mathrm{O}\right): 1.452$

$\mathrm{r}\left(\mathrm{C}^{2} \mathrm{O}\right): 1.465$

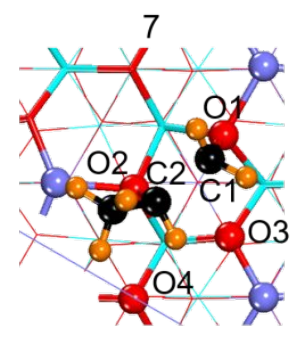

$r\left(C^{1} C^{2}\right): 1.792$

$\mathrm{r}\left(\mathrm{C}^{1} \mathrm{O}^{1}\right): 1.473$

$\mathrm{r}\left(\mathrm{C}^{1} \mathrm{O}^{3}\right): 2.670$

$\mathrm{r}\left(\mathrm{C}^{2} \mathrm{O}^{2}\right): 1.447$

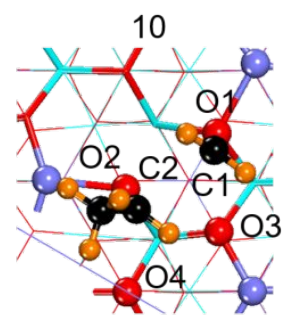

$r\left(C^{1} C^{2}\right): 2.639$

$\mathrm{r}\left(\mathrm{C}^{1} \mathrm{O}^{1}\right): 1.346$

$\mathrm{r}\left(\mathrm{C}^{1} \mathrm{O}^{3}\right): 2.690$

$\mathrm{r}\left(\mathrm{C}^{2} \mathrm{O}^{2}\right): 1.305$

$\mathrm{r}\left(\mathrm{C}^{2} \mathrm{O}^{4}\right): 2.725$

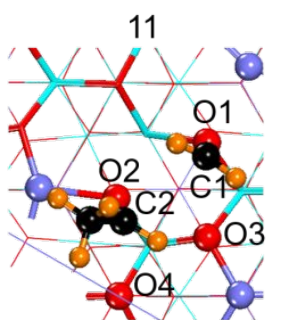

$r\left(C^{1} C^{2}\right): 2.932$

$\mathrm{r}\left(\mathrm{C}^{1} \mathrm{O}^{1}\right): 1.279$

$\mathrm{r}\left(\mathrm{C}^{1} \mathrm{O}^{3}\right): 2.681$

$\mathrm{r}\left(\mathrm{C}^{2} \mathrm{O}^{2}\right): 1.275$

$\mathrm{r}\left(\mathrm{C}^{2} \mathrm{O}^{4}\right): 2.599$

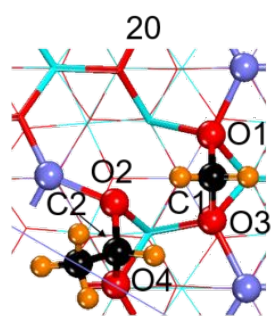

$r\left(C^{1} C^{2}\right): 3.283$

$\mathrm{r}\left(\mathrm{C}^{1} \mathrm{O}^{1}\right): 1.448$

$\mathrm{r}\left(\mathrm{C}^{1} \mathrm{O}^{3}\right): 1.456$

$r\left(C^{2} \mathrm{O}^{2}\right): 1.450$

$\mathrm{r}\left(\mathrm{C}^{2} \mathrm{O}^{4}\right): 1.447$

Figure S6. Geometry and energy changes in the $\mathrm{C}=\mathrm{C}$ bond cleavage of $\mathbf{2}^{\mathbf{B}}$ on the $\mathrm{ZnCr}_{2} \mathrm{O}_{4}(111)$ surface ( $\mathrm{Zn}$ /purple; Cr/sky blue; O/red; C/black; H/orange). The $\mathbf{2}^{\mathbf{B}}$ slightly differs from $\mathbf{2}^{\mathbf{A}}$ and $2^{\mathrm{C}}$ because their structures are taken to be favorable for the next step. Here, we investigated this reaction using $\mathbf{2}^{\mathbf{B}}$ as example because this seems good for the $\mathrm{C}=\mathrm{C}$ bond cleavage. 


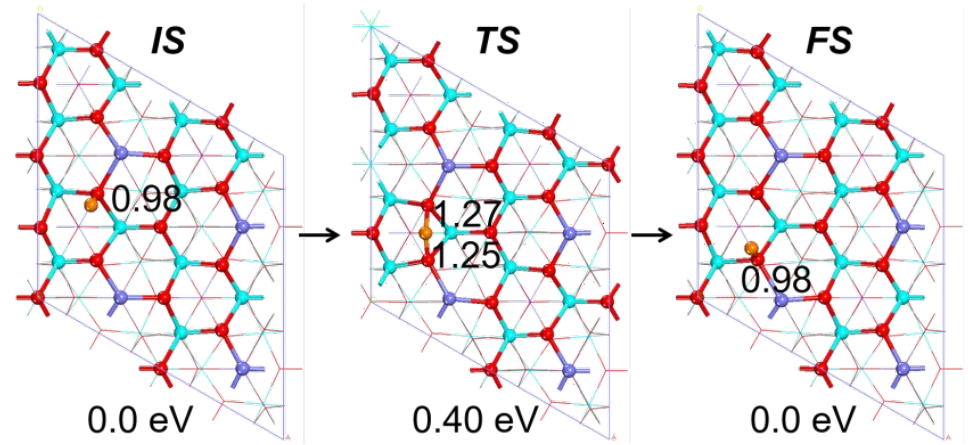

Figures S7. Geometry and energy changes in the $\mathrm{H}$ atom movements on the $\mathrm{ZnCr}_{2} \mathrm{O}_{4}(111)$ surface (Zn/purple; $\mathrm{Cr} /$ sky blue; O/red; H/orange). Bond distances are in angstrom.

Scheme S1. Reaction courses involving side-reactions in the early stage of propene combustion on the $\mathrm{ZnCr}_{2} \mathrm{O}_{4}(111)$ surface through $\mathrm{C}-\mathrm{H}$ bond activation followed by $\mathrm{O}_{\mathrm{V}}$ formation.

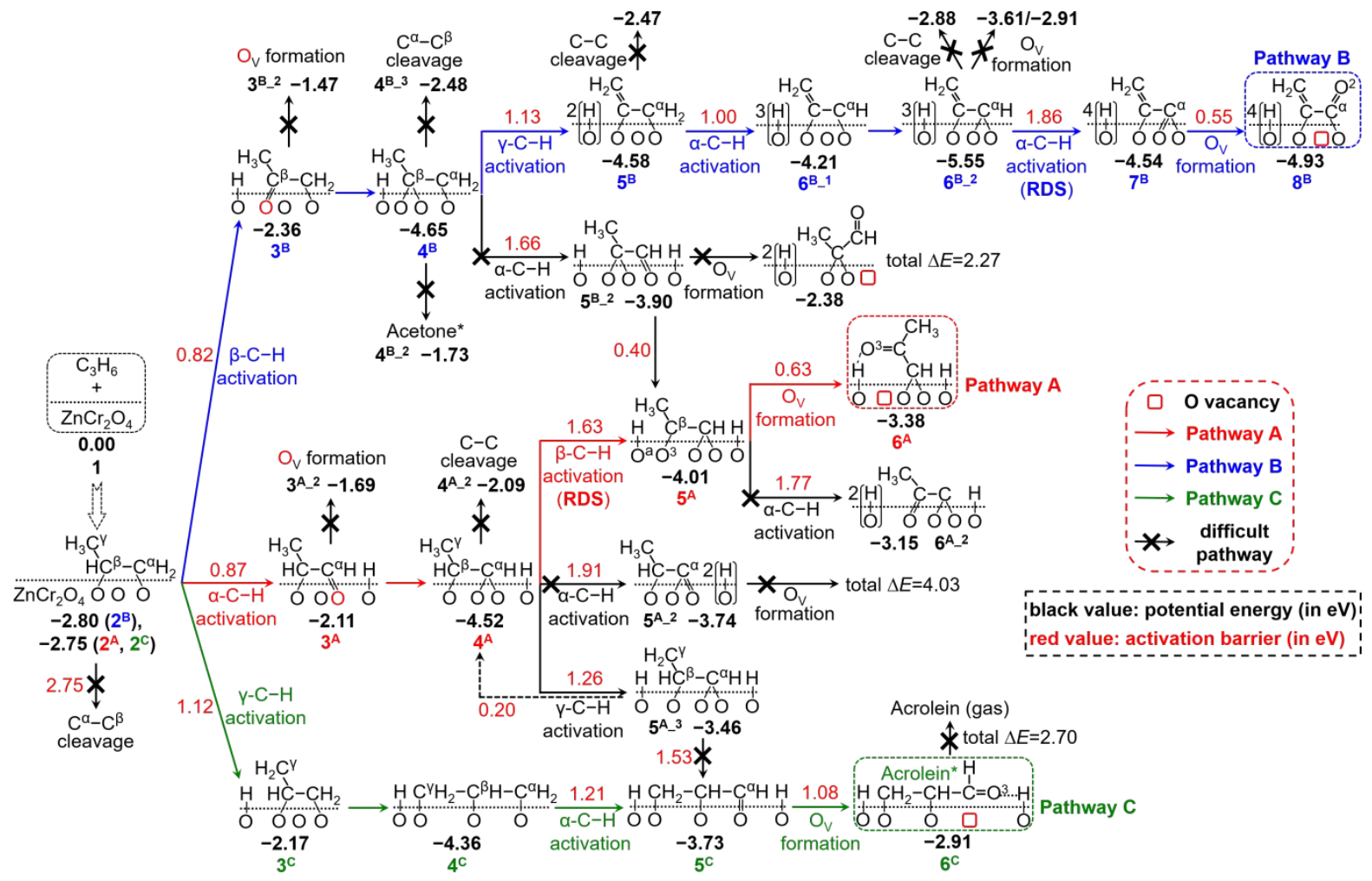


$\bullet \mathrm{H} \bullet \mathrm{C} \bullet \mathrm{O} \bullet \mathrm{O}$ in Reaction $\bullet \mathrm{Cr} \bullet \mathrm{Zn}$
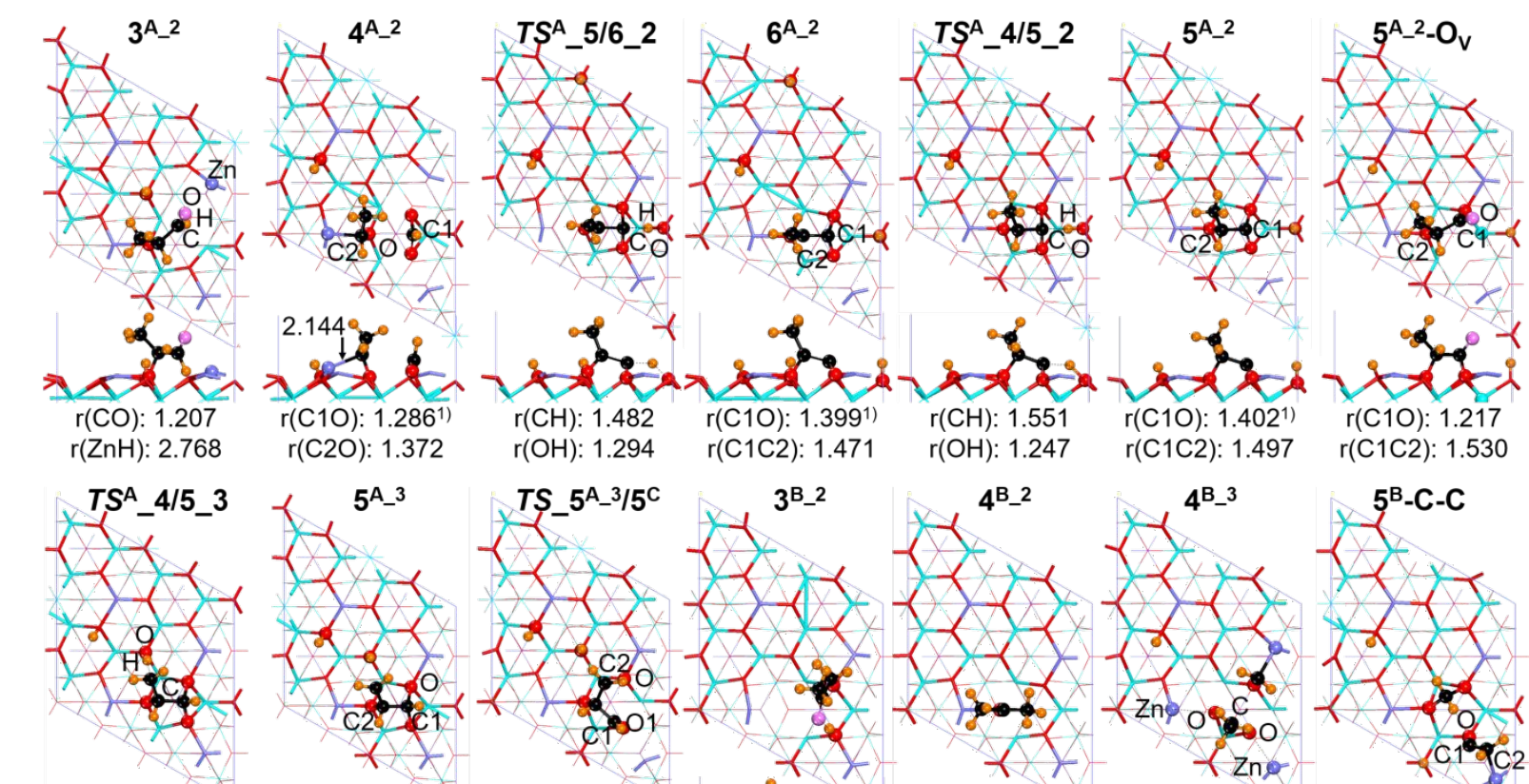

TS_ $5^{\mathrm{A}}-3^{3} \mathbf{5}^{\mathrm{C}}$
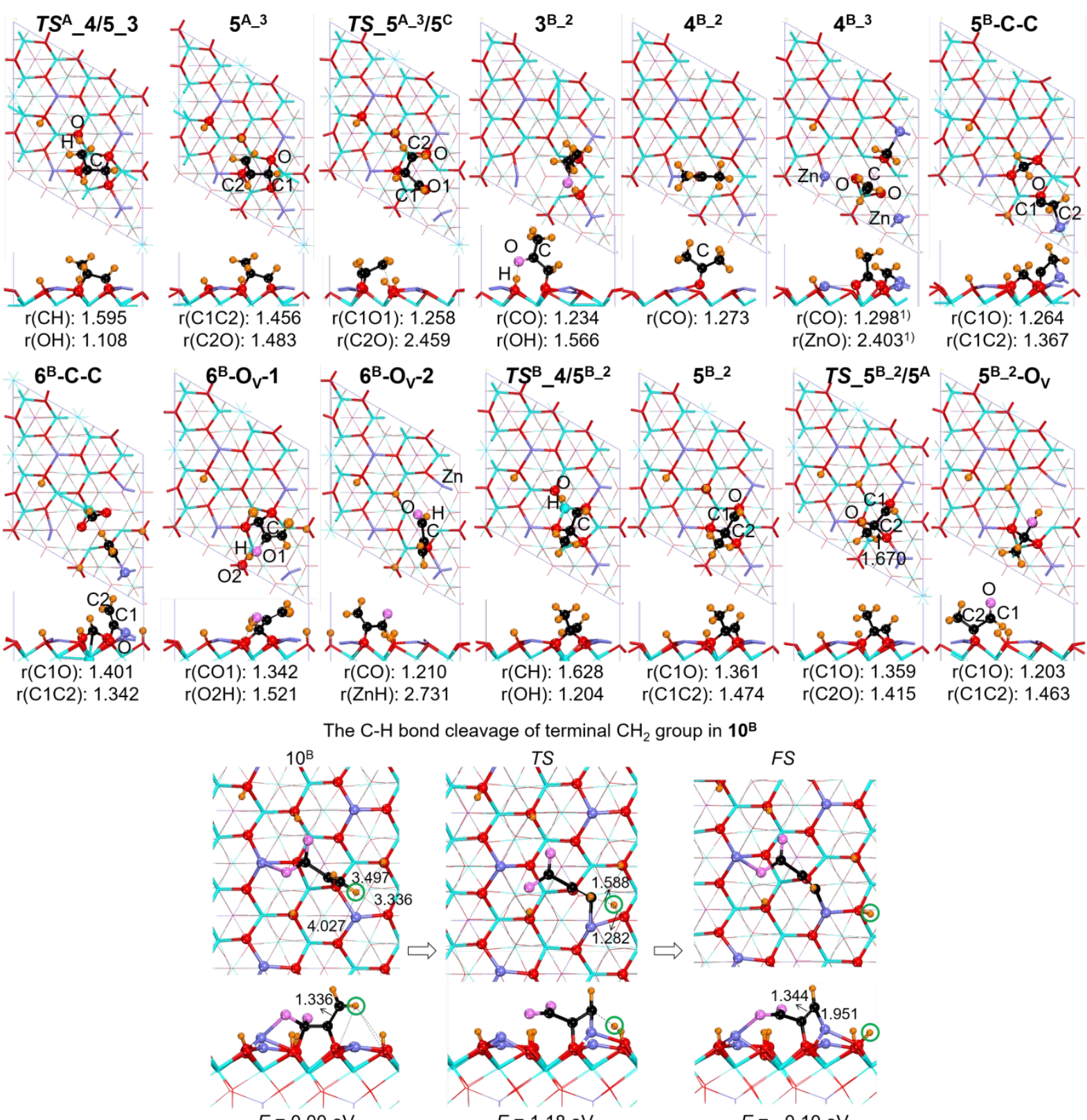

Figures S8. Geometry changes in the side-reactions at the first stage of propene combustion on the $\mathrm{ZnCr}_{2} \mathrm{O}_{4}(111)$ surface. Bond distances are in angstrom. ${ }^{1)}$ This is average value. 


\section{Discussion about side-reactions}

(1) Side-reaction of $3^{\mathbf{A}}$ and $3^{\mathbf{B}}$; Oxygen vacancy (Ov) formation seems possible in $\mathbf{3}^{\mathbf{A}}$ and $\mathbf{3}^{\mathbf{B}}$, but it is difficult to occur, as shown in Scheme S1; The geometries are shown in Figure S8.

(2) Side-reaction of $4^{\mathrm{A}}$ : The $\mathrm{C}-\mathrm{C}$ bond cleavage is difficult to occur, as shown in Scheme $\mathrm{S} 1$.

(3) The $C^{\beta}-H$ and $C^{\gamma}-H$ bond cleavages of $4^{A}$ : The $\alpha-C-H$ bond cleavage of $4^{A}$ needs a larger $E_{\mathrm{a}}$ value $(1.91 \mathrm{eV})$ to afford an intermediate $\mathbf{5}^{\mathbf{A} \_}{ }^{2}$ than the above-discussed $\beta-\mathrm{C}-\mathrm{H}$ bond cleavage (Scheme 3$)$. The $\gamma-\mathrm{C}-\mathrm{H}$ bond cleavage occurs in $\mathbf{4}^{\mathrm{A}}$ with a smaller $E_{\mathrm{a}}$ value $(1.26 \mathrm{eV})$. However, the produced intermediate $\mathrm{C}^{\gamma} \mathrm{H}_{2}{ }^{*} \mathrm{C}^{\beta} \mathrm{H}^{*} \mathrm{C}^{\alpha} \mathrm{H}^{5} \mathbf{5}^{\mathbf{A}}{ }^{3}$ is not stable, as shown in Scheme 3, because the $\gamma-\mathrm{CH}_{2}$ group has an unlikely valence state. If the $\mathrm{C}^{\gamma-\mathrm{O}_{\text {latt }}}$ bond is formed between the $\gamma-\mathrm{CH}_{2}$ group and the $\mathrm{O}_{\text {latt }}$ atom, the valence of the $\mathrm{C}^{\gamma}$ atom is satisfied. However, this step $\left(\mathbf{5}^{\mathbf{A}}{ }^{3} \rightarrow{ }^{*} \mathrm{CH}_{2}{ }^{*} \mathrm{CH}^{*} \mathrm{CH} \mathbf{5}^{\mathbf{C}}\right)$ needs a very large $E_{\mathrm{a}}$ value $\left(2.59 \mathrm{eV}\right.$ relative to $\mathbf{4}^{\mathrm{A}}$; Scheme 3$)$. The large $E_{\mathrm{a}}$ value of this step is attributed to the geometry constraint, as follows: The $\mathrm{C}^{\alpha}$ atom is bound with two $\mathrm{O}_{\text {latt }}$ atoms in $\mathbf{5}^{\mathbf{A}} \mathbf{3}^{\mathbf{3}}$. However, the $\mathrm{C}^{\gamma-} \mathrm{O}_{\text {latt }}$ bond formation in $\mathbf{5}^{\mathbf{C}}$ needs one $\mathrm{C}^{\alpha}-\mathrm{O}_{\text {latt }}$ bond cleavage because the direction of the $\mathrm{C}^{\alpha-} \mathrm{C}^{\beta}$ bond must change by the $\mathrm{C}^{\gamma-} \mathrm{O}_{\text {latt }}$ bond formation, as shown by Figure S8 of the SI. Such $\mathrm{C}^{\alpha}-\mathrm{O}_{\text {latt }}$ bond cleavage causes considerable energy destabilization. From these results, the $\alpha-\mathrm{C}-\mathrm{H}$ and $\gamma-\mathrm{C}-\mathrm{H}$ bond cleavages are ruled out in $\mathbf{4}^{\mathbf{A}}$.

(4) The side-reactions of $4^{\mathrm{B}}$ : The $\mathrm{C}-\mathrm{C}$ bond cleavage, the $\mathrm{O}_{V}$ formation, and the rebound of the adsorbed $\mathrm{H}$ atom with $\mathrm{C} 3$ species seem possible. But, all these are difficult to occur, as shown in Scheme S1.

(5) The side-reactions of $5^{\mathrm{B}}, 6^{\mathrm{B}}{ }_{-}^{2}$, and $7^{\mathrm{B}}$. In $5^{\mathrm{B}}$, the $\mathrm{C}-\mathrm{C}$ bond cleavage seems possible, but this reaction is difficult to occur, as shown in Scheme $\mathrm{S} 1$. In $\mathbf{6}^{\mathbf{B}}{ }^{2}, \mathrm{C}-\mathrm{C}$ bond cleavage and $\mathrm{O}_{\mathrm{V}}$ formation are plausible elementary steps besides $\alpha-\mathrm{C}-\mathrm{H}$ bond cleavage, while the $\gamma-\mathrm{C}-\mathrm{H}$ bond cleavage seems difficult because this $\mathrm{C}-\mathrm{H}$ bond is distant from the surface. However, the $\mathrm{C}-\mathrm{C}$ bond cleavage and $\mathrm{O}_{\mathrm{V}}$ formation are much endothermic, as shown in Scheme S1. Their $\Delta E$ values are larger than the $E_{\mathrm{a}}(1.86 \mathrm{eV})$ and $\Delta E$ values $(1.01 \mathrm{eV})$ of the $\alpha-\mathrm{C}-\mathrm{H}$ bond cleavage. Therefore, these $\mathrm{C}-\mathrm{C}$ bond cleavages and $\mathrm{O}_{\mathrm{V}}$ formation are ruled out.

In $7^{\mathbf{B}}$, besides this $\mathrm{O}_{\mathrm{V}}$ formation, the $\mathrm{C}-\mathrm{C}$ bond cleavage seems possible. But, the $\mathrm{Ov}$ formation occurs with a very small $E_{\mathrm{a}}$ value $(0.55 \mathrm{eV})$. It is unlikely that the $\mathrm{C}-\mathrm{C}$ bond cleavage can occur with a smaller Ea than this value.

(6) The $\mathbf{C}^{\gamma}-\mathbf{H}$ bond cleavage of $\mathbf{1 0}^{\mathbf{B}}$ : The $\mathrm{C}^{\gamma}-\mathrm{H}$ bond cleavage of $\mathbf{1 0}^{\mathbf{B}}$ occurs with $E_{\mathrm{a}}(1.18 \mathrm{eV})$ and $\Delta E(-0.10 \mathrm{eV})$ values relative to $\mathbf{1 0}^{\mathrm{B}}$; see geometry changes in Figure $\mathrm{S} 8$. This result shows clearly that this reaction does not occur but the reaction from $10^{\mathbf{B}} \rightarrow \mathbf{1 1}^{\mathbf{B}}$ occurs more easily $\left(E_{\mathrm{a}}\right.$ $=0.61 \mathrm{eV}, \Delta E-1.37 \mathrm{eV}$ relative to $\mathbf{1 0}^{\mathbf{B}}$ ).

(7) The possible reactions of $1^{\mathrm{B}}$ : The $\mathrm{C}^{\alpha}=\mathrm{C}^{\beta}$ bond cleavage of the ${ }^{*} C^{\alpha}=\mathrm{C}^{\beta} \mathrm{H}_{2}$ moiety is difficult to occur because it is a $\mathrm{C}=\mathrm{C}$ double bond and the $\mathrm{C}^{\beta}$ is distant from the surface. Also, $\mathrm{O}_{\mathrm{V}}$ formation is difficult to occur, as follows; because the valence of the $\mathrm{C}^{\alpha}$ atom is already satisfied, the $\mathrm{C}^{\alpha}$ cannot form a $\mathrm{C}=\mathrm{O}$ double bond by lifting up one $\mathrm{O}$ atom from the surface. Also, the $\mathrm{C}-\mathrm{H}$ bond cleavage is difficult to occur because two $\mathrm{H}$ atoms are distant from the surface (Figure $3 b$ ). Because of these reasons, $\mathbf{1 2}^{\mathbf{B}}$ is converted to a less stable ${ }^{*} \mathrm{C}^{\alpha}={ }^{*} \mathrm{C}^{\beta} \mathrm{H}_{2}$ species $\mathbf{1 3}^{\mathrm{B}}$.

(8) $\mathbf{C}-\mathbf{H}$ bond cleavage after $\mathbf{1 3}^{\mathbf{B}}$ : The $\mathrm{CH}_{2}$ group exists close to the surface in $\mathbf{1 3}^{\mathbf{B}}$, suggesting that the $\mathrm{C}-\mathrm{H}$ bond cleavage is one of plausible reactions. However, the $\mathrm{C}-\mathrm{H}$ bond cleavage 
needs considerable $E_{\mathrm{a}}$ value; for instance, $E_{\mathrm{a}}=0.82 \mathrm{eV}$ for $\mathbf{T S}^{\mathbf{B}} \_\mathbf{2} / \mathbf{3}, 1.13$ for $\mathbf{T S}^{\mathbf{B}} \mathbf{4}_{\mathbf{4}} \mathbf{5}$, and 1.00 for $\mathbf{T S}^{\mathbf{B}}{ }_{-} \mathbf{5} / \mathbf{6}$, even though they seem to occur more easily than the $\mathrm{C}-\mathrm{H}$ bond cleavage in $\mathbf{1 3}^{\mathbf{B}}$. Because the elementary step $13^{\mathrm{B}} \rightarrow \mathbf{1 4}^{\mathrm{B}}$ occurs with a moderate $E_{\mathrm{a}}$ value $(0.82 \mathrm{eV})$ being smaller than those for the $\mathrm{C}-\mathrm{H}$ bond cleavages, it is likely that this $\mathbf{1 3}^{\mathrm{B}} \rightarrow \mathbf{1 4}^{\mathrm{B}}$ step occurs more easily than the $\mathrm{C}-\mathrm{H}$ bond cleavage.

Reactions of $* \mathbf{C H}_{2}$ and $* \mathbf{C H}$ species. The $* \mathrm{CH}_{2}, * \mathrm{CH}$, and $* \mathrm{H}$ species remaining on the surface at $\mathbf{1 4}^{\mathrm{A}}$ of the pathway A and $\mathbf{1 8}^{\mathrm{B}}$ of the pathways B and C (Scheme 4 ) must be converted to $\mathrm{CO}_{2}$ and $\mathrm{H}_{2} \mathrm{O}$. Detailed explanation is presented here.

The reactions of ${ }^{*} \mathrm{CH}_{2}$ and four ${ }^{*} \mathrm{H}$ atoms, which remain at $\mathbf{1 8}^{\mathbf{B}}$ of the pathway $\mathrm{B}$, are firstly investigated here, where a new numbering system starting from $\mathbf{2 0}$ is employed hereinafter because these species are common in the pathways $\mathrm{B}$ and $\mathrm{C}$.

In the ${ }^{*} \mathrm{CH}_{2}$ group 20, two reactions are possible. One is the $\mathrm{C}-\mathrm{H}$ bond cleavage to afford a ${ }^{*} \mathrm{CH}$ species 21. This reaction occurs with an $E_{\mathrm{a}}$ value of $1.36 \mathrm{eV}$ similar to that of RDS, as shown in Figure 5a. The other reaction is the formation of formaldehyde $\mathrm{H}^{*} \mathrm{CHO}$ with simultaneous $\mathrm{O}_{\mathrm{V}}$ formation by lifting up one $\mathrm{O}_{\text {latt }}$ atom from the surface. But, this step is too endothermic $(\Delta E=2.31 \mathrm{eV})$ to occur. Thus-formed ${ }^{*} \mathrm{CH}$ species is bound with two $\mathrm{O}_{\text {latt }}$ in 21 (Figure 5b). This adsorption structure is not stable in $\mathbf{2 1}$ because the valence of the $\mathrm{C}$ atom is not satisfied. If one $\mathrm{O}_{\text {latt }}$ atom is lifted up from the surface, a formyl ( ${ }^{*} \mathrm{CHO}$ ) species 22 is formed (Figure 5b). Because the valence of the $\mathrm{C}$ atom is satisfied in the ${ }^{*} \mathrm{CHO}$ species, this step easily occurs with a moderate $E_{\mathrm{a}}$ value $(0.40 \mathrm{eV})$. In this step, the $\mathrm{O}_{\mathrm{V}}$ site is simultaneously formed on the surface. In the next step, therefore, one $\mathrm{O}_{2}$ molecule is adsorbed to the $\mathrm{O}_{\mathrm{V}}$ site with significantly large exergonicity to afford a $\left({ }^{*} \mathrm{CHO}\right)\left({ }^{*} \mathrm{O}^{\mathrm{b}}-\mathrm{O}^{\mathrm{t}}\right)$ species 23 . Because the terminal $\mathrm{O}^{t}$ atom of the adsorbed $\mathrm{O}_{2}$ molecule is reactive, two reactions are plausible. In one, the $\mathrm{O}^{t}$ atom reacts with one adsorbed ${ }^{*} \mathrm{H}$ atom to afford a hydroxyl ${ }^{*} \mathrm{OH}$ species 24 . This reaction occurs with tiny $E_{\mathrm{a}}(0.08 \mathrm{eV})$ and moderate $\Delta E(-0.13 \mathrm{eV})$ values (Figure $\left.5 \mathrm{a}\right)$. The other is the $\mathrm{H}$ transfer from the ${ }^{*} \mathrm{CHO}$ species to the $\mathrm{O}^{\mathrm{t}}$ atom. But, this needs a much larger $E_{\mathrm{a}}$ value $(0.99 \mathrm{eV}$; Figure S13 of the SI). The produced $* \mathrm{OH}$ group moves from the O_on top site to the $\mathrm{Zn}$ _on top site with considerably large exothermicity $(\Delta E=-1.46 \mathrm{eV})$ to afford a $\mathrm{Zn}$ adsorbed $\mathrm{OH}$ species 25 . This very negative $\Delta E$ is reasonable because the positively charged $\mathrm{Zn}$ atom on the surface wants to interact with the negatively charged $* \mathrm{OH}$ group. The ${ }^{*} \mathrm{OH}$ group reacts with either the surface adsorbed ${ }^{*} \mathrm{H}$ atom or the $\mathrm{H}$ atom of the $\mathrm{CHO}$ group. Because one surface ${ }^{*} \mathrm{H}$ atom exists at the position close to the ${ }^{*} \mathrm{OH}$ group $(\mathrm{R}(\mathrm{O}-\mathrm{H})=1.605$ $\AA)$, the reaction with the ${ }^{*} \mathrm{H}$ atom easily occurs to produce an ${ }^{*} \mathrm{OH}_{2}$ species 26 with tiny $E_{\mathrm{a}}$ $(0.02 \mathrm{eV})$ and moderate $\Delta E(-0.12 \mathrm{eV})$ values. These $E_{\mathrm{a}}$ and $\Delta E$ values suggest that this process is essentially the same as the equilibrium between the adsorbed ${ }^{*} \mathrm{OH}_{2}$ and the adsorbed $* \mathrm{H}$ and ${ }^{*} \mathrm{OH}$ species. The other reaction with the ${ }^{*} \mathrm{CHO}$ species occurs via $\mathrm{H}$ transfer from the ${ }^{*} \mathrm{CHO}$ to the $* \mathrm{OH}$ group, but it needs a larger $E_{\mathrm{a}}$ value $\left(0.58 \mathrm{eV}\right.$; Figure $\mathrm{S} 14$ of the SI). After $\mathrm{H}_{2} \mathrm{O}$ desorption, the formyl $\left({ }^{*} \mathrm{CHO}\right)$ species 27 remains on the surface. This formyl undergoes the $\mathrm{C}-\mathrm{H}$ bond cleavage to generate adsorbed ${ }^{*} \mathrm{H}$ and ${ }^{*} \mathrm{CO}$ species 28 with an $E_{\mathrm{a}}$ value of $1.09 \mathrm{eV}$ and moderate $\Delta E$ value of $-0.34 \mathrm{eV}$. Recently reported theoretical work demonstrated that $* \mathrm{CO}$ reacts with $\mathrm{O}_{\text {latt }}$ to yield $\mathrm{CO}_{2}$ and one $\mathrm{O}_{\mathrm{V}}$ site with an $E_{\mathrm{a}}$ value of $1.00 \mathrm{eV}$ on $\mathrm{ZnCr}_{2} \mathrm{O}_{4}(111){ }^{48}$ Once the $\mathrm{O}_{\mathrm{V}}$ site is formed, one $\mathrm{O}_{2}$ molecule is easily adsorbed at the $\mathrm{O}_{\mathrm{V}}$ site. The $\mathrm{O}^{\mathrm{t}}$ atom 
reacts with the two remaining $* \mathrm{H}$ atoms to yield $\mathrm{H}_{2} \mathrm{O}$ through transition states TS_30/31 and TS_32/33, as shown by the $\mathbf{3 0} \rightarrow \mathbf{3 3}$ step in Figure $5 \mathrm{~b}$. The $E_{\mathrm{a}}$ is very small $(0.06 \mathrm{eV}$ for TS_30/31 and $0.02 \mathrm{eV}$ for TS_32/33), because the strong $\mathrm{O}-\mathrm{H}$ bond is formed via TS_30/31 and thermodynamically stable $\mathrm{H}_{2} \mathrm{O}$ is produced via TS_32/33. After $\mathrm{H}_{2} \mathrm{O}$ desorption, two adsorbed ${ }^{*} \mathrm{H}$ atoms still remain on the surface. Thus, it is concluded that the ${ }^{*} \mathrm{CH}_{2}$ and two ${ }^{*} \mathrm{H}$ atoms are converted to $\mathrm{CO}_{2}$ and two $\mathrm{H}_{2} \mathrm{O}$ molecules, where the largest $E_{\mathrm{a}}(1.66 \mathrm{eV})$ is needed at the formation of the formyl species followed by the $\mathrm{O}_{\mathrm{V}}$ formation $(\mathbf{2 0} \rightarrow \mathbf{2 2})$ (Figure $5 \mathrm{~b}$ ). However, two $* \mathrm{H}$ atoms still remain on the surface, as shown in Scheme 4, indicating that the complete combustion of propene is not achieved along the pathways $\mathrm{B}$ and $\mathrm{C}$.

At $14^{\mathrm{A}}$ of the pathway A, ${ }^{*} \mathrm{CH}_{2},{ }^{*} \mathrm{CH}$, and three ${ }^{*} \mathrm{H}$ species remain on the surface (Scheme 4). Among them, ${ }^{*} \mathrm{CH}_{2}$ and two $* \mathrm{H}$ atoms are converted to $\mathrm{CO}_{2}$ and two $\mathrm{H}_{2} \mathrm{O}$ molecules, as discussed above and shown by Figure 5. Therefore, one ${ }^{*} \mathrm{CH}$ and one ${ }^{*} \mathrm{H}$ species remain on the surface. The ${ }^{*} \mathrm{CH}$ species in $\mathbf{1 4}^{\mathbf{A}}$ is bound with three $\mathrm{O}_{\text {latt }}$ atoms. This ${ }^{*} \mathrm{CH}$ species is more stable than the ${ }^{*} \mathrm{CH}$ species bound with two $\mathrm{O}_{\text {latt }}$ atoms (21 in Figure 5) by $0.53 \mathrm{eV}$. One plausible reaction of this $* \mathrm{CH}$ species is the formation of ${ }^{*} \mathrm{CHO}$ and one $\mathrm{O}_{\mathrm{V}}$ site by lifting up one $\mathrm{O}_{\text {latt }}$ atom from the surface. However, this ${ }^{*} \mathrm{CHO}$ species could not be located because the ${ }^{*} \mathrm{CHO}$ species was converted to ${ }^{*} \mathrm{CH}$ bound with three $\mathrm{O}_{\text {latt }}$ atoms (the species $\mathbf{1 4}^{\mathrm{A}}$ ) during the geometry optimization. The other plausible reaction is isomerization of this $* \mathrm{CH}$ species to a different $* \mathrm{CH}$ form bound with two $\mathrm{O}_{\text {latt }}$ atoms. This conversion occurs with moderate $\Delta E$ value $(0.53 \mathrm{eV})$, as shown by Figure $\mathrm{S} 15$ of the SI. The ${ }^{*} \mathrm{CH}$ species bound with two $\mathrm{O}_{\text {latt }}$ atoms is already investigated in $\mathbf{2 1}$ (Figure 5), which shows that the ${ }^{*} \mathrm{CH}$ species is converted to a formyl *CHO species by lifting up one of the $\mathrm{O}_{\text {latt }}$ atoms from the surface with simultaneous formation of one $\mathrm{O}_{\mathrm{V}}$ site. The $\mathrm{O}_{\mathrm{V}}$ site undergoes $\mathrm{O}_{2}$ adsorption. Its $\mathrm{O}^{\mathrm{t}}$ atom easily reacts with the ${ }^{*} \mathrm{H}$ atom to afford ${ }^{*} \mathrm{OH}$ group with a tiny $E_{\mathrm{a}}$ value $(0.08 \mathrm{eV})$, as shown by the $\mathbf{2 3} \rightarrow \mathbf{2 4}$ step in Figure 5 . Another plausible reaction is the $\mathrm{H}$ transfer from the ${ }^{*} \mathrm{CHO}$ to the $\mathrm{O}^{\mathrm{t}}$ atom. But, this $\mathrm{H}$ transfer needs a larger $E_{\mathrm{a}}$ value than the ${ }^{*} \mathrm{OH}$ formation $(\mathbf{2 3} \rightarrow \mathbf{2 4})$, as discussed above and Figure $\mathrm{S} 13$ of the SI. Then, the $\mathrm{H}$ atom of the formyl ${ }^{*} \mathrm{CHO}$ reacts with the ${ }^{*} \mathrm{OH}$ to afford $\mathrm{H}_{2} \mathrm{O}$ molecule with a moderate $E_{\mathrm{a}}$ value of $0.58 \mathrm{eV}$, as shown by Figure S14 of the SI; this step more easily occurs than the $\mathrm{H}$ transfer from * $\mathrm{CHO}$ to the surface $\mathrm{O}_{\text {latt }}$ atom (the $\mathbf{2 7} \rightarrow \mathbf{2 8}$ step; $E_{\mathrm{a}}=1.09 \mathrm{eV}$ ). Though one $\mathrm{CO}$ remains on the surface, it is converted to $\mathrm{CO}_{2}$ with simultaneous formation of one $\mathrm{O}_{\mathrm{V}}$ site with an $E_{\mathrm{a}}$ value of $1.0 \mathrm{eV}$, as shown by the $\mathbf{2 8} \rightarrow \mathbf{2 9}$ step in Figure 5a. Thus, the ${ }^{*} \mathrm{CH}+{ }^{*} \mathrm{H}$ is easily converted to $\mathrm{CO}_{2}$ and $\mathrm{H}_{2} \mathrm{O}$ with the formation of one $\mathrm{O}_{\mathrm{V}}$ site in the pathway $\mathrm{A}$, as shown in Scheme 4. This $\mathrm{O}_{\mathrm{V}}$ site undergoes easily $\mathrm{O}_{2}$ adsorption to provide a reactive $\mathrm{O}^{\mathrm{t}}$ atom in the pathway A (Scheme 4 and $\mathbf{3 0}$ in Figure 5). These results indicate that the complete combustion of propene cannot be achieved along the pathway A, too.

In the reaction of $* \mathrm{CH}_{2}+4 * \mathrm{H}$ on the pathways $\mathrm{B}$ and $\mathrm{C}$, two $* \mathrm{H}$ atoms remain on the surface after formation of one $\mathrm{CO}_{2}$ and two $\mathrm{H}_{2} \mathrm{O}$ molecules, as discussed above. The $\mathrm{O}^{\mathrm{t}}$ of the adsorbed $\mathrm{O}_{2}$ molecule reacts with one of those two ${ }^{*} \mathrm{H}$ atoms to afford ${ }^{*} \mathrm{OH}$, as shown by the $\mathbf{3 0} \rightarrow \mathbf{3 1}$ step of Figure 5. This $* \mathrm{OH}$ reacts with remaining $* \mathrm{H}$ to afford one $\mathrm{H}_{2} \mathrm{O}$ molecule, as shown by the $\mathbf{3 1} \rightarrow \mathbf{3 3}$ step of Figure 5 . The $E_{\mathrm{a}}$ is moderate for these two steps. 

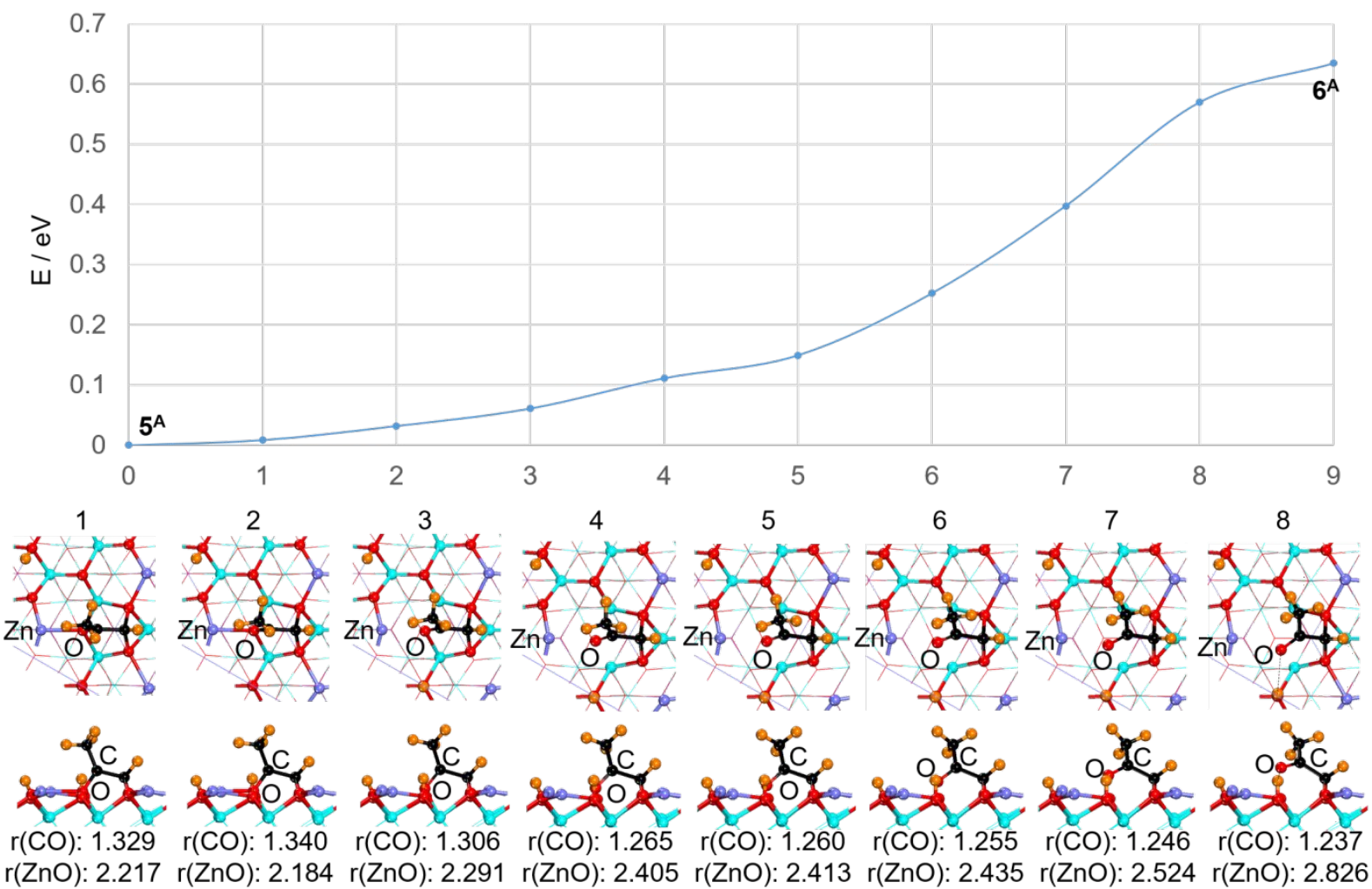

Figures S9. Energy and geometry changes in the $\mathbf{5}^{\mathbf{A}} \rightarrow \mathbf{6}^{\mathbf{A}}$ step on the $\mathrm{ZnCr}_{2} \mathrm{O}_{4}(111)$ surface (Zn/purple; Cr/sky blue; O/red; C/black; H/orange). Bond distances are in angstrom. We carried out NEB calculation using $\mathbf{5}^{\mathbf{A}}$ and $\mathbf{6}^{\mathbf{A}}$. These geometry and energy changes were taken from the NEB computational results.

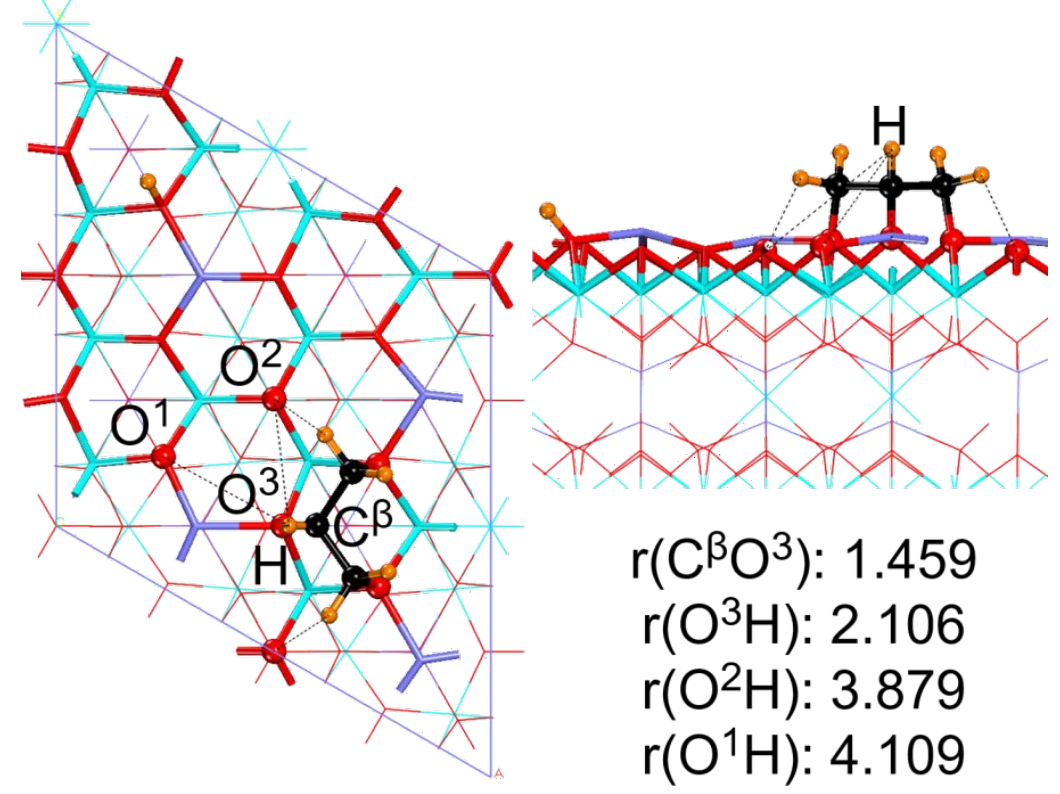

Figures S10. Geometry of $4^{\mathrm{C}}$ on the $\mathrm{ZnCr}_{2} \mathrm{O}_{4}(111)$ surface ( $\mathrm{Zn} /$ purple; $\mathrm{Cr} /$ sky blue; O/red; $\mathrm{C} /$ black; H/orange). Bond distances are in angstrom. 

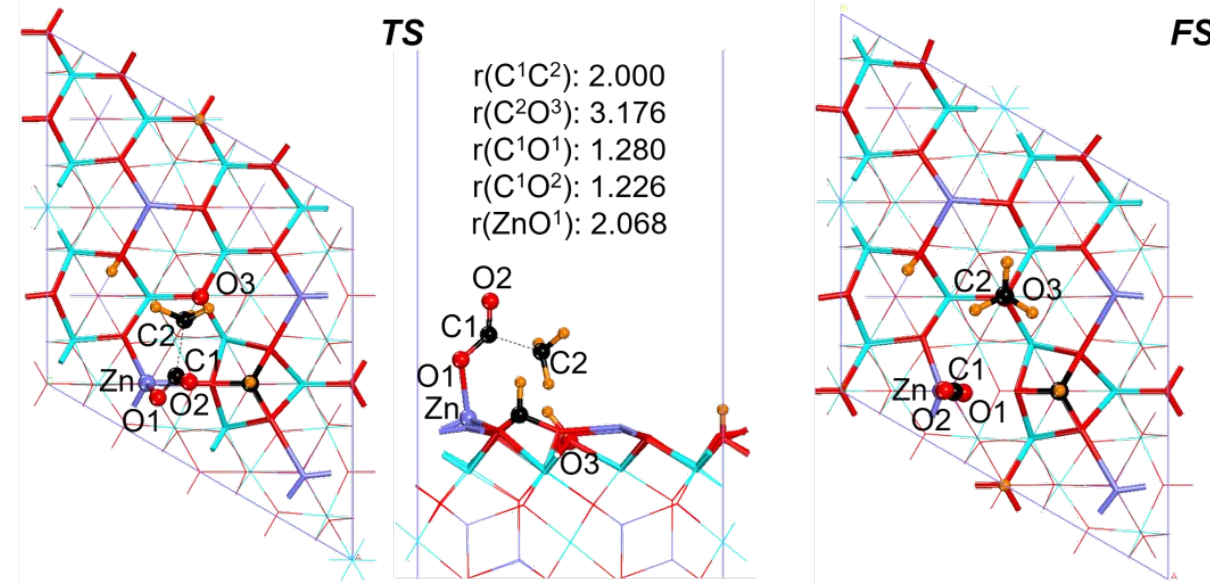

FS

$\mathrm{r}\left(\mathrm{C}^{2} \mathrm{O}^{3}\right): 1.437$

$\mathrm{r}\left(\mathrm{C}^{1} \mathrm{O}^{1}\right): 1.180$

$\mathrm{r}\left(\mathrm{C}^{1} \mathrm{O}^{2}\right): 1.173$

$\mathrm{r}\left(\mathrm{ZnO}^{1}\right): 2.678$

Figures S11. Structural parameters of the transition state and final species in the $\mathrm{C}-\mathrm{C}$ bond cleavage of $\mathrm{CH}_{3}-\mathrm{COO}^{*}$ species 10 ${ }^{\mathrm{A}}$ ( $\mathrm{Zn}$ /purple; $\mathrm{Cr} /$ sky blue; O/red; C/black; H/orange). Bond distances are in angstrom. 


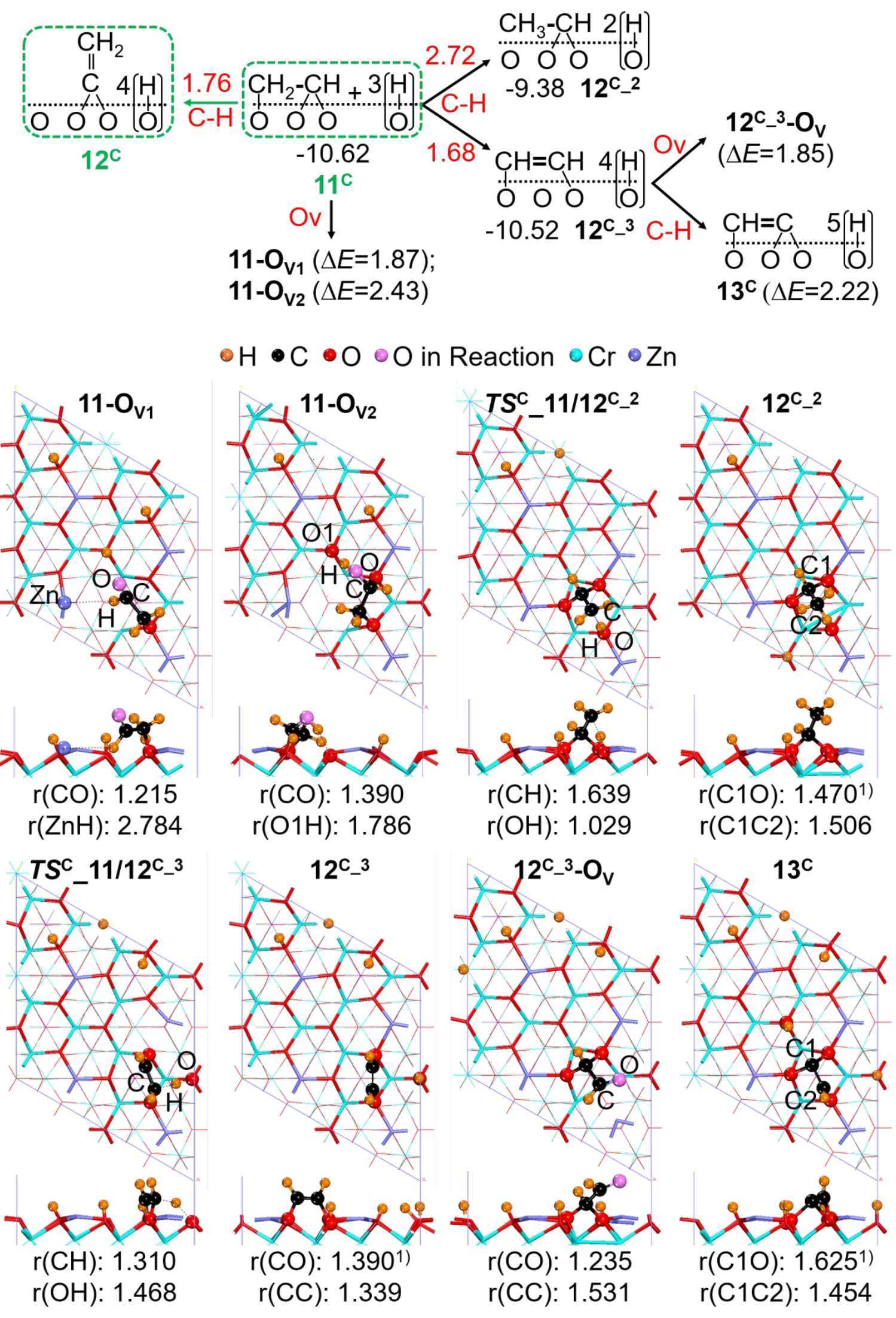

Figure S12. Energy (above) and geometry (below) changes in the combustion of $* \mathrm{C}=\mathrm{CH}_{2} \mathbf{1 1}^{\mathrm{C}}$ on the $\mathrm{ZnCr}_{2} \mathrm{O}_{4}(111)$ surface. Bond distances are in angstrom. ${ }^{1)}$ This is average value. 
TS

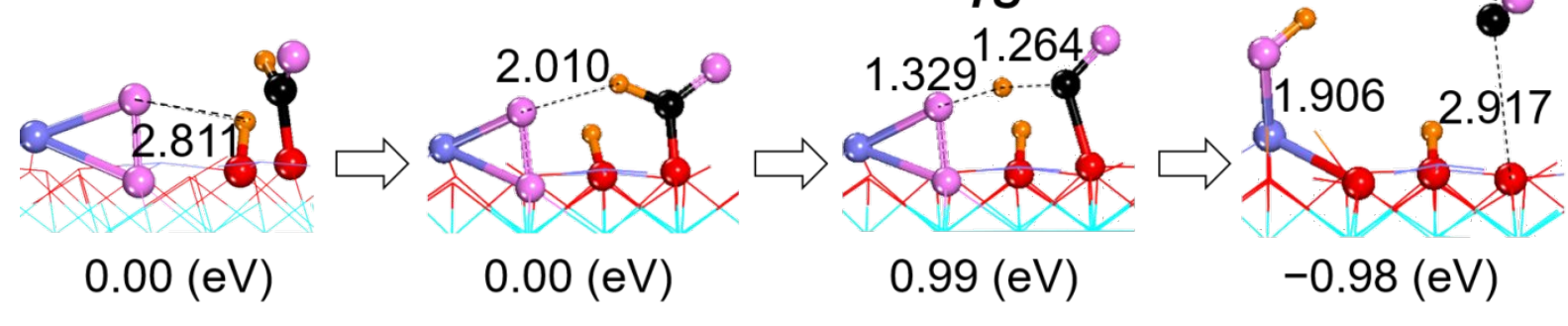

Figure S13. Energy and geometry changes in the reaction of ${ }^{*} \mathrm{CHO}$ and terminal $\mathrm{O}\left(\mathrm{O}^{\mathrm{t}}\right)$ atom of adsorbed $\mathrm{O}_{2}$ molecule on the $\mathrm{ZnCr}_{2} \mathrm{O}_{4}(111)$. Bond distances are in angstrom.

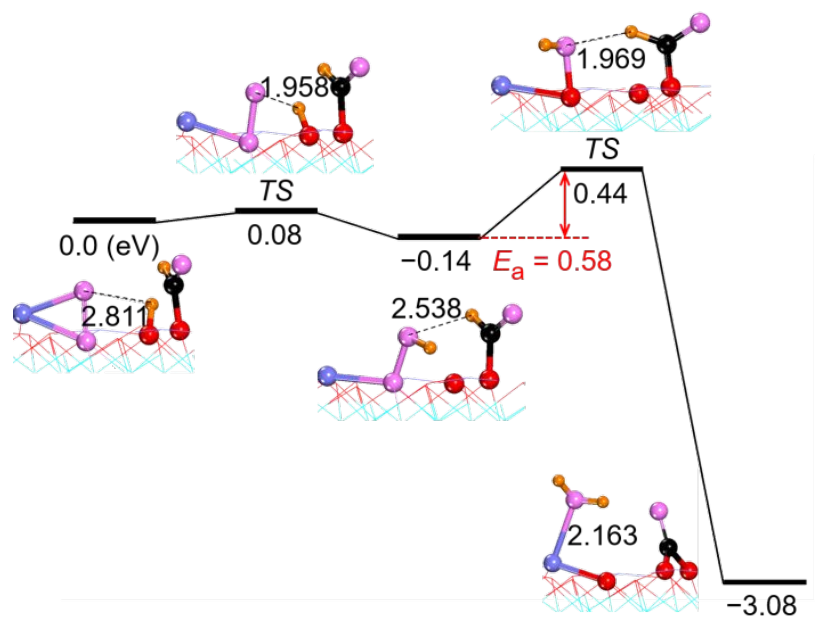

Figure S14. Energy and geometry changes in the reaction of ${ }^{*} \mathrm{CH}$ and ${ }^{*} \mathrm{H}$ on the $\mathrm{ZnCr}_{2} \mathrm{O}_{4}(111)$.
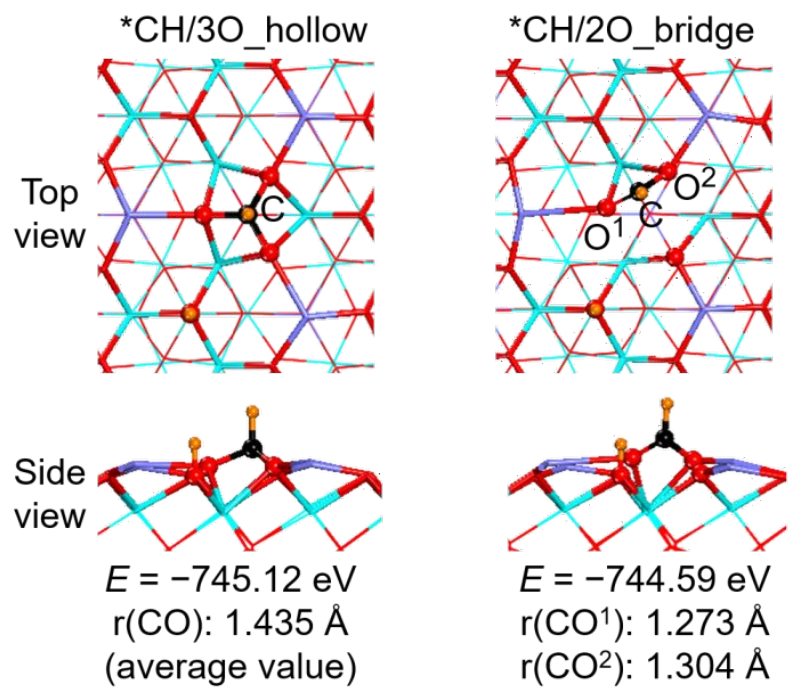

Figure S15. Co-adsorption structure and energy of ${ }^{*} \mathrm{CH}$ and ${ }^{*} \mathrm{H}$ on the $\mathrm{ZnCr}_{2} \mathrm{O}_{4}(111)$. 
$\bullet \mathrm{H} \bullet \mathrm{C} \bullet \mathrm{O} \bullet \mathrm{O}$ in Reaction $\bullet \mathrm{M}^{\mathrm{Oh}} \bullet \mathrm{M}^{\mathrm{Td}}$

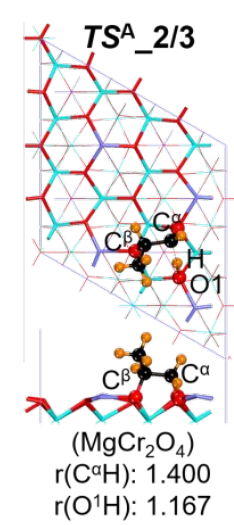

$\left(\mathrm{Zn}_{1-\mathrm{x}} \mathrm{Cu}_{\mathrm{x}} \mathrm{Cr}_{2} \mathrm{O}_{4}\right)$ $\mathrm{r}\left(\mathrm{C}^{\alpha} \mathrm{H}\right): 1.327$ $\mathrm{r}\left(\mathrm{O}^{1} \mathrm{H}\right): 1.214$

$\left(\mathrm{ZnCr}_{2-\mathrm{x}} \mathrm{Co}_{\mathrm{x}} \mathrm{O}_{4}\right)$ $\mathrm{r}\left(\mathrm{C}^{\mathrm{a}} \mathrm{H}\right): 1.232$ $\mathrm{r}\left(\mathrm{O}^{1} \mathrm{H}\right): 1.386$
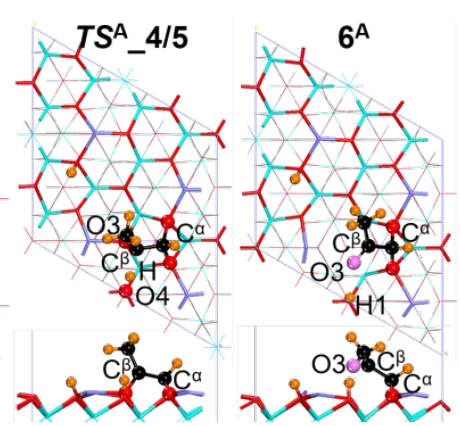

$\left(\mathrm{MgCr}_{2} \mathrm{O}_{4}\right)$ $\mathrm{r}\left(\mathrm{C}^{\beta} \mathrm{H}\right): 1.645$ $\mathrm{r}\left(\mathrm{O}^{4} \mathrm{H}\right): 1.195$

$\left(\mathrm{Zn}_{1-\mathrm{x}} \mathrm{Cu}_{\mathrm{x}} \mathrm{Cr}_{2} \mathrm{O}_{4}\right)$ $\mathrm{r}\left(\mathrm{C}^{\beta} \mathrm{H}\right): 1.592$ $\mathrm{r}\left(\mathrm{O}^{4} \mathrm{H}\right): 1.240$

$\left(\mathrm{ZnCr}_{2-\mathrm{x}} \mathrm{Co}_{\mathrm{x}} \mathrm{O}_{4}\right)$ $\mathrm{r}\left(\mathrm{C}^{\beta} \mathrm{H}\right): 1.420$ $\mathrm{r}\left(\mathrm{O}^{4} \mathrm{H}\right): 1.364$

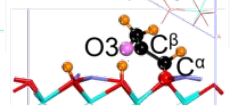

$\left(\mathrm{MgCr}_{2} \mathrm{O}_{4}\right)$ $r\left(\mathrm{C}^{\beta} \mathrm{O}^{3}\right): 1.242$

$\left(\mathrm{Zn}_{1-\mathrm{x}} \mathrm{Cu}_{\mathrm{x}} \mathrm{Cr}_{2} \mathrm{O}_{4}\right)$ $\mathrm{r}\left(\mathrm{C}^{\beta} \mathrm{O}^{3}\right): 1.232$ $\mathrm{r}\left(\mathrm{O}^{3} \mathrm{H}^{1}\right): 2.180$

$\left(\mathrm{ZnCr}_{2-\mathrm{x}} \mathrm{Co}_{\mathrm{x}} \mathrm{O}_{4}\right)$ $r\left(\mathrm{C}^{\beta} \mathrm{O}^{3}\right): 1.233$ $\mathrm{r}\left(\mathrm{O}^{3} \mathrm{H}^{1}\right): 2.348$ $r\left(\mathrm{O}^{3} \mathrm{H}^{1}\right): 2.335$
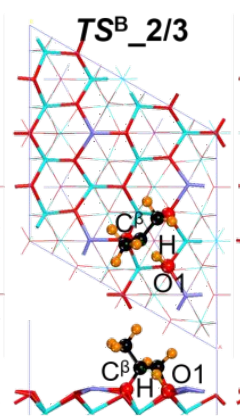

$\left(\mathrm{MgCr}_{2} \mathrm{O}_{4}\right)$ $\mathrm{r}\left(\mathrm{O}^{1} \mathrm{H}\right): 1.185$ $r\left(C^{\beta} H\right): 1.395$

$\left(\mathrm{Zn}_{1-\mathrm{x}} \mathrm{Cu}_{\mathrm{x}} \mathrm{Cr}_{2} \mathrm{O}_{4}\right)$ $\mathrm{r}\left(\mathrm{O}^{1} \mathrm{H}\right): 1.264$ $r\left(C^{\beta} H\right): 1.308$

$\left(\mathrm{ZnCr}_{2-\mathrm{x}} \mathrm{Co}_{\mathrm{x}} \mathrm{O}_{4}\right)$ $\mathrm{r}\left(\mathrm{O}^{1} \mathrm{H}\right): 1.264$ $\mathrm{r}\left(\mathrm{C}^{\beta} \mathrm{H}\right): 1.397$
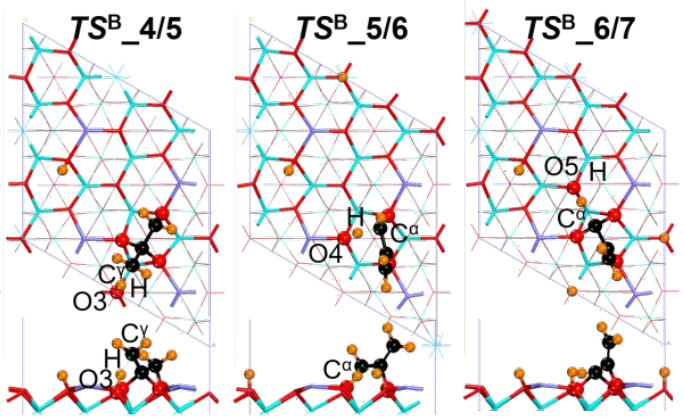

$\left(\mathrm{MgCr}_{2} \mathrm{O}_{4}\right)$ $\mathrm{r}\left(\mathrm{O}^{3} \mathrm{H}\right): 1.104$ $\mathrm{r}(\mathrm{CrH}): 1.657$
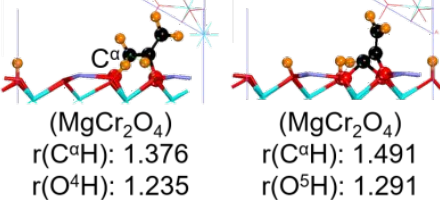

$\left(\mathrm{MgCr}_{2} \mathrm{O}_{4}\right)$

$\mathrm{r}\left(\mathrm{C}^{\mathrm{a}} \mathrm{H}\right): 1.491$

$r\left(\mathrm{O}^{5} \mathrm{H}\right): 1.291$

$\left(\mathrm{Zn}_{1-\mathrm{x}} \mathrm{Cu}_{\mathrm{x}} \mathrm{Cr}_{2} \mathrm{O}_{4}\right)$ $\mathrm{r}\left(\mathrm{O}^{3} \mathrm{H}\right): 1.385$ $\mathrm{r}(\mathrm{CrH}): 1.314$

$\left(\mathrm{Zn}_{1-\mathrm{x}} \mathrm{Cu}_{\mathrm{x}} \mathrm{Cr}_{2} \mathrm{O}_{4}\right)$ $r\left(\mathrm{C}^{\alpha} \mathrm{H}\right): 1.337$ $\mathrm{r}\left(\mathrm{O}^{4} \mathrm{H}\right): 1.255$

$\left(\mathrm{Zn}_{1-\mathrm{x}} \mathrm{Cu}_{\mathrm{x}} \mathrm{Cr}_{2} \mathrm{O}_{4}\right)$ $\mathrm{r}\left(\mathrm{C}^{\mathrm{a}} \mathrm{H}\right): 1.361$ $r\left(\mathrm{O}^{5} \mathrm{H}\right): 1.250$

$\left(\mathrm{ZnCr}_{2-\mathrm{x}} \mathrm{Co}_{\mathrm{x}} \mathrm{O}_{4}\right)$ $\mathrm{r}\left(\mathrm{O}^{3} \mathrm{H}\right): 1.390$ $\mathrm{r}(\mathrm{CrH}): 1.311$
$\left(\mathrm{ZnCr}_{2-\mathrm{x}} \mathrm{Co}_{\mathrm{x}} \mathrm{O}_{4}\right)$ $\mathrm{r}\left(\mathrm{C}^{\alpha} \mathrm{H}\right): 1.238$ $\mathrm{r}\left(\mathrm{O}^{4} \mathrm{H}\right): 1.404$
$\left(\mathrm{ZnCr}_{2-\mathrm{x}} \mathrm{Co}_{\mathrm{x}} \mathrm{O}_{4}\right)$ $r\left(\mathrm{C}^{\mathrm{a}} \mathrm{H}\right): 1.530$ $\mathrm{r}\left(\mathrm{O}^{5} \mathrm{H}\right): 1.251$

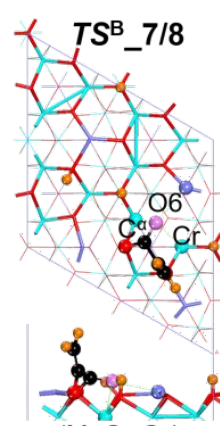

$\left(\mathrm{MgCr}_{2} \mathrm{O}_{4}\right)$ $r\left(\mathrm{C}^{\alpha} \mathrm{O}^{6}\right): 1.288$ $\mathrm{r}\left(\mathrm{CrO}^{6}\right): 2.891^{1)}$

$\left(\mathrm{Zn}_{1-\mathrm{x}} \mathrm{Cu}_{\mathrm{x}} \mathrm{Cr}_{2} \mathrm{O}_{4}\right)$ $\mathrm{r}\left(\mathrm{C}^{\mathrm{a}} \mathrm{O}^{6}\right): 1.258$ $\left.\mathrm{r}\left(\mathrm{CrO}^{6}\right): 2.636^{1}\right)$

$\left(\mathrm{ZnCr}_{2-\mathrm{x}} \mathrm{Co}_{\mathrm{x}} \mathrm{O}_{4}\right)$ $\mathrm{r}\left(\mathrm{C}^{\mathrm{a}} \mathrm{O}^{6}\right): 1.259$ $\mathrm{r}\left(\mathrm{CoO}^{6}\right): 2.781^{1)}$
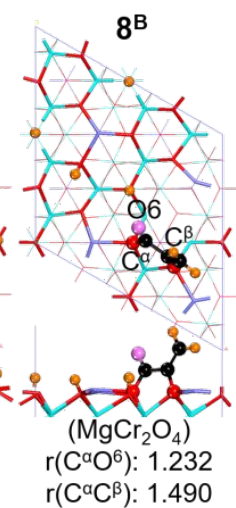

$\left(\mathrm{Zn}_{1-\mathrm{x}} \mathrm{Cu}_{\mathrm{x}} \mathrm{Cr}_{2} \mathrm{O}_{4}\right)$ $r\left(\mathrm{C}^{\alpha} \mathrm{O}^{6}\right): 1.220$ $r\left(C^{\alpha} C^{\beta}\right): 1.503$

$\left(\mathrm{ZnCr}_{2-\mathrm{x}} \mathrm{Co}_{\mathrm{x}} \mathrm{O}_{4}\right)$ $r\left(\mathrm{C}^{\alpha} \mathrm{O}^{6}\right): 1.225$ $r\left(C^{\alpha} C^{\beta}\right): 1.505$

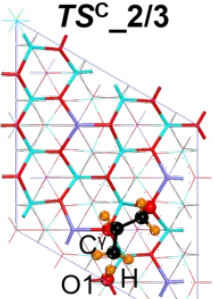

$T S^{C}{ }_{-4 / 5}$
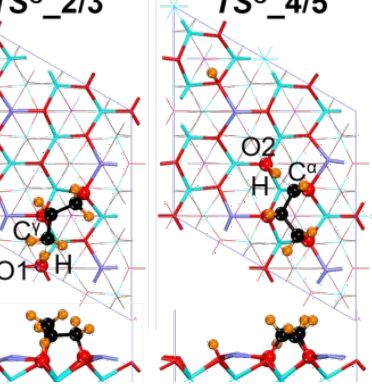

$\left(\mathrm{MgCr}_{2} \mathrm{O}_{4}\right)$ $r\left(\mathrm{O}^{1} \mathrm{H}\right): 1.171$ $\mathrm{r}(\mathrm{CrH}): 1.520$

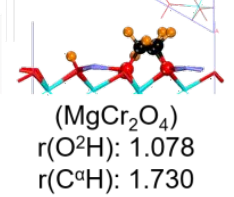

$\left(\mathrm{Zn}_{1-\mathrm{x}} \mathrm{Cu}_{\mathrm{x}} \mathrm{Cr}_{2} \mathrm{O}_{4}\right)$ $\mathrm{r}\left(\mathrm{O}^{1} \mathrm{H}\right): 1.222$ $\mathrm{r}(\mathrm{CrH}): 1.445$

$\left(\mathrm{ZnCr}_{2-\mathrm{x}} \mathrm{Co}_{\mathrm{x}} \mathrm{O}_{4}\right)$ $\mathrm{r}\left(\mathrm{O}^{1} \mathrm{H}\right): 1.277$ $\mathrm{r}(\mathrm{CrH}): 1.334$
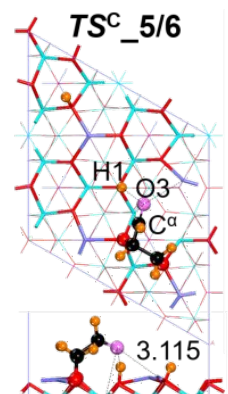

$\left(\mathrm{MgCr}_{2} \mathrm{O}_{4}\right)$ $r\left(\mathrm{C}^{\alpha} \mathrm{O}^{3}\right): 1.228$ $r\left(\mathrm{O}^{3} \mathrm{H}^{1}\right): 2.150$

$\left(\mathrm{Zn}_{1-\mathrm{x}} \mathrm{Cu}_{\mathrm{x}} \mathrm{Cr}_{2} \mathrm{O}_{4}\right)$ $r\left(\mathrm{C}^{\mathrm{a}} \mathrm{O}^{3}\right): 1.227$ $\mathrm{r}\left(\mathrm{O}^{3} \mathrm{H}^{1}\right): 1.800$

$\left(\mathrm{ZnCr}_{2-\mathrm{x}} \mathrm{Co}_{\mathrm{x}} \mathrm{O}_{4}\right)$ $\mathrm{r}\left(\mathrm{C}^{\mathrm{a}} \mathrm{O}^{3}\right): 1.225$ $\mathrm{r}\left(\mathrm{O}^{3} \mathrm{H}^{1}\right): 2.063$
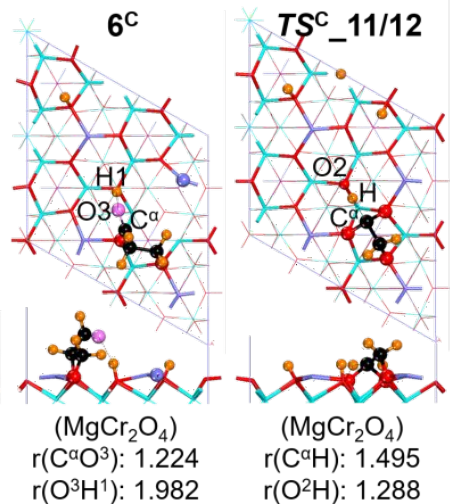

$\left(\mathrm{MgCr}_{2} \mathrm{O}_{4}\right)$

$\mathrm{r}\left(\mathrm{C}^{\mathrm{a}} \mathrm{H}\right): 1.495$ $\mathrm{r}\left(\mathrm{O}^{2} \mathrm{H}\right): 1.288$

$\left(\mathrm{Zn}_{1-\mathrm{x}} \mathrm{Cu}_{\mathrm{x}} \mathrm{Cr}_{2} \mathrm{O}_{4}\right) \quad\left(\mathrm{Zn}_{1-\mathrm{x}} \mathrm{Cu}_{\mathrm{x}} \mathrm{Cr}_{2} \mathrm{O}_{4}\right)$ $\mathrm{r}\left(\mathrm{C}^{\mathrm{a}} \mathrm{O}^{3}\right): 1.225 \quad \mathrm{r}\left(\mathrm{C}^{\mathrm{a}} \mathrm{H}\right): 1.528$ $\mathrm{r}\left(\mathrm{O}^{3} \mathrm{H}^{1}\right): 1.804 \quad \mathrm{r}\left(\mathrm{O}^{2} \mathrm{H}\right): 1.253$

$\left(\mathrm{ZnCr}_{2-\mathrm{x}} \mathrm{Co}_{\mathrm{x}} \mathrm{O}_{4}\right)$ $\mathrm{r}\left(\mathrm{C}^{\mathrm{a}} \mathrm{O}^{3}\right): 1.223$ $\mathrm{r}\left(\mathrm{O}^{3} \mathrm{H}^{1}\right): 2.079$
$\left(\mathrm{ZnCr}_{2-x} \mathrm{Co}_{x} \mathrm{O}_{4}\right)$ $\mathrm{r}\left(\mathrm{C}^{\mathrm{a}} \mathrm{H}\right): 1.411$ $\mathrm{r}\left(\mathrm{O}^{2} \mathrm{H}\right): 1.351$

Figure S16. Geometry changes in the propene combustion on the $\operatorname{MgCr}_{2} \mathrm{O}_{4}(111)$, $\mathrm{Zn}_{1-\mathrm{x}} \mathrm{Cu}_{\mathrm{x}} \mathrm{Cr}_{2} \mathrm{O}_{4}(111)$, and $\mathrm{ZnCr}_{2-\mathrm{x}} \mathrm{Co}_{\mathrm{x}} \mathrm{O}_{4}(111)$ surfaces. Bond distances are in angstrom. ${ }^{1)}$ This is average value. 
(a) Pathway A

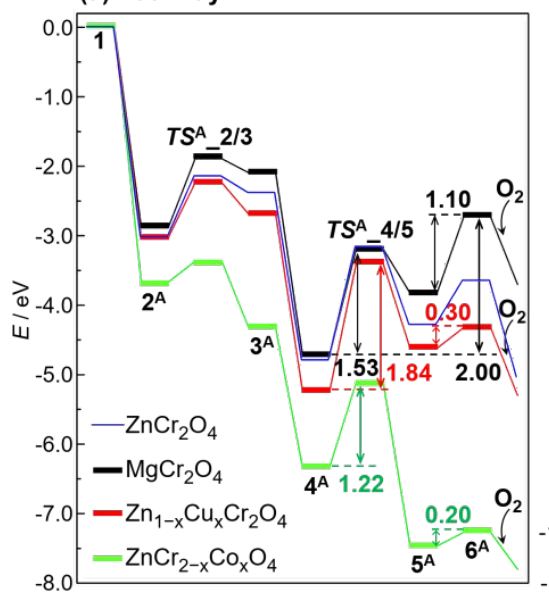

(b) Pathway B

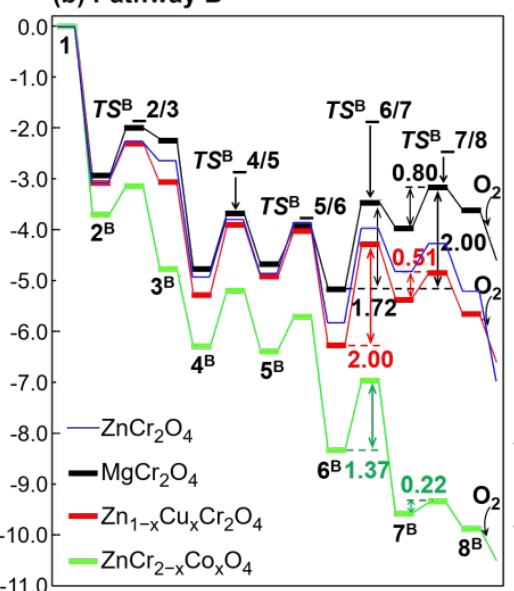

(c) Pathway C

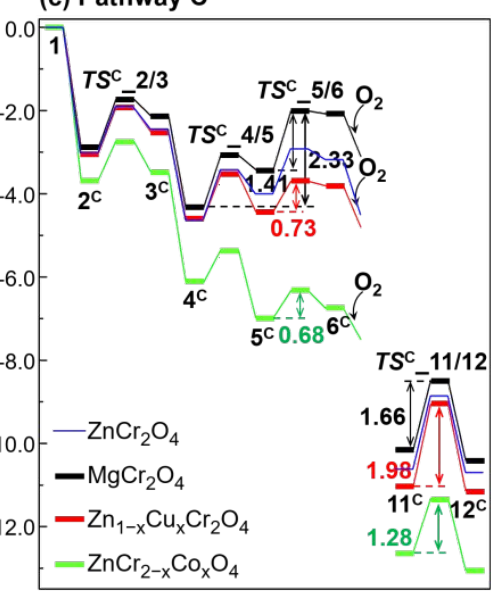

Figure S17. Energy profiles of propene combustion on $\mathrm{MgCr}_{2} \mathrm{O}_{4}(111), \mathrm{Zn}_{1-\mathrm{x}} \mathrm{Cu}_{\mathrm{x}} \mathrm{Cr}_{2} \mathrm{O}_{4}(111)$,

$\mathrm{ZnCr}_{2-\mathrm{x}} \mathrm{Co}_{\mathrm{x}} \mathrm{O}_{4}(111)$, and $\mathrm{ZnCr}_{2} \mathrm{O}_{4}(111)$ surfaces via the pathway A (a), pathway B (b), and pathway $\mathrm{C}(\mathrm{c})$. 
Table S3. Energy changes ( $E$, in eV) in propene combustion on the $\mathrm{MgCr}_{2} \mathrm{O}_{4}(111), \mathrm{Zn}_{1-\mathrm{x}} \mathrm{Cu}_{\mathrm{x}} \mathrm{Cr}_{2} \mathrm{O}_{4}(111)$, and $\mathrm{ZnCr}_{2-\mathrm{x}} \mathrm{Co}_{\mathrm{x}} \mathrm{O}_{4}(111)$ surfaces.

\begin{tabular}{|c|c|c|c|c|c|c|c|c|c|c|c|c|}
\hline$E(\mathrm{eV})$ & $2^{\mathrm{A}}$ & $\mathrm{TS}^{\mathrm{A}} \_2 / 3$ & $\mathbf{3}^{\mathbf{A}}$ & $4^{\mathrm{A}}$ & $\mathrm{TS}^{\mathrm{A}}{ }_{-4 / 5}$ & $5^{A}$ & $6^{\mathrm{A}}$ & & & & & \\
\hline $\mathrm{MgCr}_{2} \mathrm{O}_{4}$ & -2.89 & $-1.89-$ & -2.09 & -4.72 & -3.19 & -3.83 & -2.73 & & & & & \\
\hline $\mathrm{Zn}_{1-\mathrm{x}} \mathrm{Cu}_{\mathrm{x}} \mathrm{Cr}_{2} \mathrm{O}$ & $4-3.03$ & -2.24 & -2.69 & -5.24 & -3.40 & -4.62 & -4.32 & & & & & \\
\hline $\mathrm{ZnCr}_{2-\mathrm{x}} \mathrm{Co}_{\mathrm{x}} \mathrm{O}$ & -3.67 & $-3.37-$ & -4.33 & -6.33 & -5.11 & -7.47 & -7.27 & & & & & \\
\hline$E(\mathrm{eV})$ & $2^{\text {B }}$ & $\mathrm{TS}^{\mathrm{B}} \_2 / 3$ & $3^{\mathbf{B}}$ & $4^{\mathrm{B}}$ & $\mathrm{TS}^{\mathrm{B}}{ }_{4} / \mathbf{5}$ & $5^{\mathrm{B}}$ & $\mathrm{TS}^{\mathrm{B}}{ }_{-5 / 6}$ & $6^{\mathrm{B}}$ & TS $^{B}{ }_{-6} / 7$ & $7^{\mathrm{B}}$ & TS $_{-7 / 8}$ & $88^{B}$ \\
\hline $\mathrm{MgCr}_{2} \mathrm{O}_{4}$ & -2.97 & -2.00 & -2.21 & -4.79 & -3.67 & -4.69 & -3.94 & -5.16 & $6 \quad-3.44$ & -3.96 & -3.16 & -3.62 \\
\hline $\mathrm{Zn}_{1-\mathrm{x}} \mathrm{Cu}_{\mathrm{x}} \mathrm{Cr}_{2} \mathrm{O}$ & $4-3.06$ & -2.29 & -3.08 & -5.28 & -3.92 & -4.94 & -4.01 & -6.28 & $8-4.29$ & -5.35 & -4.84 & -5.67 \\
\hline $\mathrm{ZnCr}_{2-\mathrm{x}} \mathrm{Co}_{\mathrm{x}} \mathrm{O}$ & $4-3.71$ & -3.14 & -4.75 & -6.31 & -5.19 & -6.38 & -5.70 & -8.34 & $4 \quad-6.97$ & -9.57 & -9.36 & -9.87 \\
\hline$E(\mathrm{eV})$ & $2^{\mathrm{C}}$ & $\mathrm{TS}^{\mathrm{C}} \_2 / 3$ & $3^{C}$ & $4^{C}$ & $T S^{C} \_4 / 5$ & $55^{C}$ & $\mathrm{TS}^{\mathrm{C}}{ }_{5} / 6$ & $66^{C}$ & $11^{\mathrm{C}}$ & $T^{C}{ }_{-11 / 12}$ & $12^{\mathrm{C}}$ & \\
\hline $\mathrm{MgCr}_{2} \mathrm{O}_{4}$ & -2.89 & -1.72 & -2.13 & -4.35 & -3.07 & -3.42 & -2.01 & -2.08 & $8-10.16$ & -8.49 & -10.41 & \\
\hline $\mathrm{Zn}_{1-\mathrm{x}} \mathrm{Cu}_{\mathrm{x}} \mathrm{Cr}_{2} \mathrm{O}$ & $4-3.03$ & $-1.92-$ & -2.51 & -4.62 & -3.54 & -4.43 & -3.70 & -3.81 & $1-11.04$ & -9.06 & -11.14 & \\
\hline $\mathrm{ZnCr}_{2-\mathrm{x}} \mathrm{Co}_{\mathrm{x}} \mathrm{O}$ & $4-3.67$ & -2.72 & -3.48 & -6.14 & -5.34 & -6.98 & -6.33 & -6.75 & $5-12.61$ & -11.33 & -13.05 & \\
\hline
\end{tabular}

